\title{
BETTER THAN BASIC INCOME? LIBERTY, EQUALITY, AND THE REGULATION OF W ORKING TIME
}

\author{
MATTHEW DiMICK*
}

\begin{abstract}
Basic income has attracted the attention of academics, policy makers, and politicians around the globe. Basic income-a no-strings-attached cash transfer made to all citizens of a country, rich or poor-has been lauded as a plan to eliminate poverty, reduce income inequality, redress imbalances in the labor market, remedy the impending problem of mass technology-induced unemployment - the "robot apocalypse"—and make possible meaningful lives for those otherwise dependent on menial work in the labor market. It has also been proposed as an efficient, nonpaternalistic, and stigma-free alternative to existing welfare state policies. This Article compares basic income to an alternative policy proposal: the regulation of maximum working hours in the labor market. This Article contends that on nearly all of these virtues, working-time regulation does better than, or at least as well as, basic income. In particular, working-time regulation makes "free time" available to a broader array of individuals, also addresses technological unemployment, and is much more conducive to proenvironmental policies. Most importantly, it is more deeply egalitarian than basic income, not only addressing income inequality but social inequality, as well. Although basic income and working-time regulation are not necessarily incompatible -indeed some have advocated the adoption of both policies-there may be other factors that effectively render them policy substitutes. Specifically, not only is working-time regulation more complementary to existing welfare-state policy than is basic income, but-already in existence in the U.S. and most other developed countries-it also does not face the challenges of political and economic feasibility that confront basic income. Thus the choice and comparison is a compelling one, of which legal, policy, and tax scholars should take note.
\end{abstract}

* Associate Professor of Law, University at Buffalo School of Law. Direct correspondence to: 618 John Lord O’Brian Hall, Buffalo, N.Y. 14260-1100. E-mail: mdimick@buffalo.edu. For comments and discussion, thanks are owed to Andrea Boyack, Sam Brunson, Brigham Daniels, Kristen Dimick, Frederick Gedicks, Nicole Hallet, Jim Rasband, Jack Schlegel, Matt Steilen, and Jim Wooten. Particular thanks are owed to Todd Brown and Rick Su for acting as discussants at a UB School of Law workshop. For excellent research assistance, I wish to thank (in alphabetical order) Steve Fisher and Rasmus Rosenberg Larsen.

http://doi.org/10.18060/4806.1144 
For many ages to come the old Adam will be so strong in us that everybody will need to do some work if he is to be contented. We shall do more things for ourselves than is usual with the rich to-day, only too glad to have small duties and tasks and routines. But beyond this, we shall endeavour to spread the bread thin on the butter-to make what work there is still to be done to be as widely shared as possible. Three-hour shifts or a fifteen-hour week may put off the problem for a great while. For three hours a day is quite enough to satisfy the old Adam in most of us!

John Maynard Keynes ${ }^{1}$

\section{INTRODUCTION}

As Vox journalist Dylan Matthews wrote, "Basic income is having a moment." Basic income is an unconditional-no strings attached-cash transfer, made to all citizens or residents of a country. Once merely an academic idea, today " $[\mathrm{t}]$ he governments of Finland, Ontario, and Utrecht are all launching tests of the policy proposal." Moreover, "The charity GiveDirectly is set to give basic incomes to 6,000 people in Kenya, and the tech industry powerhouse $Y$ Combinator is funding an experiment evaluating the idea." ${ }^{4}$ In its largest advance to date, a basic income proposal was put to a referendum vote in Switzerland. ${ }^{5}$ Although the proposal failed, that such a plan was voted on at all is rather momentous. ${ }^{6}$

Basic income has also captured the attention of politicians, policy wonks, and other "thought leaders" outside the ivory tower. ${ }^{7}$ Andy Stern-former head of the

1. John Maynard Keynes, Economic Possibilities for our Grandchildren, in ESSAYS IN Persuasion 321, 328-29 (3d ed. 2010).

2. Dylan Matthews, Basic Income: The World's Simplest Plan to End Poverty, Explained, Vox (Apr. 25, 2016), http://www.vox.com/2014/9/8/6003359/basic-income-negative-income-taxquestions-explain [https://perma.cc/KA4W-MRNC].

3. $I d$.

4. Id.

5. Raphael Minder, Guaranteed Income for All? Switzerland's Voters Say No Thanks, N.Y. TiMEs (June 5, 2016), https://www.nytimes.com/2016/06/06/world/europe/switzerland-swiss-votebasic-income.html?_r=1 [https://perma.cc/2CT6-AJJK].

6. Id. (noting "campaigners said the vote was a first step" and quoting an economics professor who backed the initiative and stated that "[o]ne out of five people voted for the unconditional basic income, so that is a success in itself').

7. Basic income is not necessarily a new idea, however. Milton Friedman, the well-known libertarian economist, was "[a]rguably the biggest popularizer" of a version of basic income. Matthews, supra note 2. Martin Luther King, Jr. also advocated a guaranteed income. Id. Many influential economists of previous decades have favored a basic income. Id. Even Presidents Richard Nixon and Jimmy Carter supported a "negative income tax" - a policy very similar to a basic income - and this legislation even came close to passing through the legislature. Id. 
influential Service Employees International Union-recently wrote a book, Raising the Floor, in which he made a major case for basic income. ${ }^{8}$ Presidential candidate Bernie Sanders "expressed sympathy" for the idea, although he did not endorse it. ${ }^{9}$ Basic income was recently the subject of several articles and a debate in the New York Times ${ }^{10}$ and appears regularly in the popular media. ${ }^{11}$ Nobel-

8. See generally ANDy Stern, RAising THE FloOR: How A Universal BASIC InCOME CAN Renew Our ECONOMy And Rebuild the American Dream (2016).

9. Matthews, supra note 2.

10. Farhad Manjoo, A Plan in Case Robots Take the Jobs: Give Everyone a Paycheck, N.Y. TiMES (Mar. 3, 2016), http://www.nytimes.com/2016/03/03/technology/plan-to-fight-robotinvasion-at-work-give-everyone-a-paycheck.html [https://perma.cc/3A9F-ZCTG]; Eduardo Porter, A Universal Basic Income is a Poor Tool to Fight Poverty, N.Y. TIMEs (May 31, 2016), https://www.nytimes.com/2016/06/01/business/economy/universal-basic-income-poverty.html [https://perma.cc/P8A4-ASC4]; Eduardo Porter \& Farhad Manjoo, A Future Without Jobs? Two Views of the Changing Work Force, N.Y. Times (Mar. 8, 2016), http://www.nytimes.com/ 2016/03/09/business/economy/a-future-without-jobs-two-views-of-the-changing-work-force.html [https://perma.cc/9PWJ-8FPT].

11. See, e.g., Mike Konczal, These Policies Could Move America Toward a Universal Basic Income, NATION (Aug. 1, 2016), https://www.thenation.com/article/these-policies-could-moveamerica-toward-a-universal-basic-income/ [https://perma.cc/Y3SX-S986]; Greg Ip, Revival of Universal Basic Income Proposal Ignores Needs of Labor Force, WaLl ST. J. (July 13, 2016), http://www.wsj.com/articles/revival-of-universal-basic-income-proposal-ignores-needs-of-laborforce-1468429793 [https://perma.cc/LSZ3-46ZH]; Samuel Hammond, When the Welfare State Met the Flat Tax, ForeIgn POL'y (June 16, 2016), http://foreignpolicy.com/2016/06/16/when-thewelfare-state-met-the-flat-tax/ [https://perma.cc/6D3G-MVS7]; James Surowiecki, The Case for Free Money: Why Don't We Have Universal Basic Income?, New Yorker (June 20, 2016), http://www.newyorker.com/magazine/2016/06/20/why-dont-we-have-universal-basic-income [https://perma.cc/MXS9-MSNS]; Noah Smith, Silicon Valley's Basic-Income Experiment Is Worth Watching, BloOMBerG VIEw (June 8, 2016), https://www.bloomberg.com/view/articles/2016-0608/silicon-valley-s-basic-income-experiment-is-worth-watching [https://perma.cc/8N77-BM24]; Perry Stein, Is a Basic Income Possible in D. C.? The City Is Looking Into It, WASH. Post (June 7, 2016), https://www.washingtonpost.com/news/local/wp/2016/06/07/is-a-basic-income-possible-ind-c-the-city-is-looking-into-it/?utm_term=.614a8a8d150f [https://perma.cc/ZC3W-2JNL]; Will Heilpern, How the Universal Basic Income Scheme Could Save Us When Robots Take Our Jobs, BUS. INSIDER (June 7, 2016), http://www.businessinsider.com/compass-universal-basic-incomereport-qa-2016-6 [https://perma.cc/8MTR-73KT]; Paul Solman, Why Universal Basic Income Isn't Going Away Any Time Soon, PBS Newshour (June 7, 2016), http://www.pbs.org/newshour/ making-sense/why-universal-basic-income-isnt-going-away-any-time-soon/ [https://perma.cc/EF48-8D26]; Megan McArdle, Universal Basic Income Is Ahead of Its Time (to Say the Least), BLOOMBERG VIEW (June 6, 2016), https://www.bloomberg.com/view/articles/201606-06/universal-basic-income-is-ahead-of-its-time-to-say-the-least [https://perma.cc/AQ8XDSYL]; Noah Gordon, The Conservative Case for a Guaranteed Basic Income, ATLANTIC (Apr. 6, 2014), http://www.theatlantic.com/politics/archive/2014/08/why-arent-reformicons-pushing-aguaranteed-basic-income/375600/ [https://perma.cc/E8Y9-KGEP]. 
prize winning economists have signaled their support for the policy. ${ }^{12}$

For supporters, basic income does several things: it eliminates poverty; counters rising income inequality; non-paternalistically promotes freedom because recipients are free to use their basic income in whatever way they deem appropriate, in contrast to traditional means-tested and in-kind welfare state policies; and it offers a solution to what many fear is the approaching apocalypse of technological unemployment. Central to its appeal-and this Article-basic income eliminates dependence on the labor market and makes possible meaningful lives not dictated by market imperatives.

The goal of this Article is to compare basic income ${ }^{13}$ with another policy: the regulation of working hours. ${ }^{14}$ The novel contribution is that, despite initial impressions, both basic income and working-hours regulation have, surprisingly, implications for an identical list of normative criteria. Both have consequences for broad normative principles, such as enhancing individual liberty ${ }^{15}$ and increasing social and economic equality. ${ }^{16}$ But they also have implications for addressing more fine-grained issues such as technological unemployment, ${ }^{17}$ the nature of work, ${ }^{18}$ and the environment. ${ }^{19}$ Because it is an important concern for political sustainability, basic income and working-hours regulation can also be evaluated in terms of what is called their "universality."20 Thus, despite first appearances, basic income and working-hours regulation are quite normatively comparable.

Besides this comparative analysis, this Article also contends that workingtime regulation is a superior alternative to basic income. Not only do basic income and working-hours regulation fulfill similar normative aspirations, but regulation possesses most, if not all, of the advantages of basic income and few of its disadvantages. ${ }^{21}$ In addition, the advantages of basic income are perhaps not as great as proponents believe. Furthermore, untested and untried to any serious extent anywhere in the world, basic income faces very real issues of both economic and political feasibility. ${ }^{22}$ As an alternative to basic income, this Article proposes a simple extension of an already existing policy solution: the regulation of maximum working hours.

This Article will compare basic income and working-hours regulation along several dimensions. But one point of comparison deserves special mention:

12. Matthews, supra note 2 ("Nobel prize winning economists like Christopher Pissarides and Joseph Stiglitz have gotten on board recently as well.”).

13. See infra Part I.

14. See infra Part II.

15. See infra Part III.A.

16. See infra Part III.B.

17. See infra Part III.C.

18. See infra Part III.D.

19. See infra Part III.G.

20. See infra Part III.E.

21. See infra Part III.

22. See infra Part III.D. 
equality. Basic income is almost always put forward as an egalitarian policy, one that can directly, dramatically, and even efficiently redress poverty and economic inequality. ${ }^{23}$ Yet, although basic income may indeed ameliorate income inequality - though, as I will note, there are limitations here, too - it may actually exacerbate social inequality. There is much more to equality than simply the distribution of income. And in these aspects, basic income may do more harm than good. In contrast, working-hours regulation will-perhaps surprisingly-do much more to reduce social inequalities than will basic income. This claim may constitute the strongest argument in favor of choosing the regulation of working time over basic income.

Besides their overlooked comparability, there are several other reasons to analyze basic income and working-time regulation in conjunction. One reason is to contribute to a larger debate about the choice between the legal system and the tax system to accomplish distributive or egalitarian objectives. ${ }^{24}$ This choice comes in several versions, but they can be summarized by the sentiment that to reduce inequality, markets should be left alone, and taxes and transfers should be the sole means of redistribution. For example, the political philosopher John Rawls wrote, "once a suitable minimum is provided by transfers, it may be perfectly fair that the rest of total income be settled by the price system."25 Similarly, in a famous article, legal economists Louis Kaplow and Steven Shavell make an efficiency argument that the tax system, rather than the legal system, should be the sole method for redistributing income. ${ }^{26}$ Basic income-a pure taxand-transfer scheme- and working-hours regulation - a classic market regulating mechanism-typify this choice. By demonstrating the advantages of workinghours regulation, this Article challenges conventional wisdom and concludes that the legal system can indeed be a more compelling choice than the tax system.

Another reason for comparing basic income and working-hours regulation is that such a contrast contributes to the discussion about policy choice under political and, specifically, democratic constraints. Much-especially academic-discussion about policy is overly philosophical, focusing on fundamental normative principles. But many non-normative constraints also influence what policies are possible — not just desirable. These include political

23. See infra Part III.B.

24. See Ronen Avraham et al., Revisiting the Roles of Legal Rules and Tax Rules in Income Redistribution: A Response to Kaplow \& Shavell, 89 IowA L. REV. 1125, 1127 (2004); Tomer Blumkin \& Yoram Margalioth, On The Limits of Redistributive Taxation: Establishing a Case for Equity-Informed Legal Rules, 25 VA. TAX REV. 1, 2 (2005); Matthew Dimick, Should the Law Do Anything About Economic Inequality?, 26 Cornell J.L. \& PuB. Pol'y 1, 28 (2016); Zachary Liscow, Reducing Inequality on the Cheap: When Legal Rule Design Should Incorporate Equity as Well as Efficiency, 123 YALE L.J. 2478, 2480 \& n.2 (2014); Lee Anne Fennell \& Richard H. McAdams, The Distributive Deficit in Law and Economics (Univ. Chi. Law Sch. Coase-Sandor

Working Paper Series in Law and Econ., Working Paper No. 713, 2015).

25. John RAwls, A Theory of Justice 277 (1971).

26. Louis Kaplow \& Steven Shavell, Why the Legal System Is Less Efficient Than the Income Tax in Redistributing Income, 23 J. LEGAL STUD. 667, 667-68 (1994). 
institutions, political capital, path dependencies, and institutional complementarities, to name but a few. For example, as a large political literature suggests, how countries regulate financial markets depends a lot on how they regulate labor markets. Therefore, however much we may find a piece of financial regulation normatively attractive, implementing that regulation may depend-positively_on the nature of surrounding rules, institutions, and interests. ${ }^{27}$

Basic income and working-time regulation gives us a good example of this problem. On an abstract philosophical level, these policies are not necessarily substitutes. That is, there is no particular normative reason why a country could not have both basic income and stricter regulation of working time. Indeed, there are some authors who have argued precisely for both. ${ }^{28}$ Nevertheless, real-world, existing constraints-limits in political capital, political feasibility, path dependency, etc. - may make such a choice necessary. In particular, basic income represents a quite novel, "disruptive" and "post-industrial" approach to welfare reform. Working-time regulation-which in some fashion already exists in every developed country-is far more consistent with welfare-state policy as it currently exists. Consequently, basic income may generate substantial tensions with the existing institutional environment of mature welfare states. To the extent that this is true-and makes each policy institutional if not normative substitutes - this Article offers some reasons for why working-time regulation can be preferred to basic income. Furthermore, this Article should not be read as a rejection of basic income as a policy proposal by itself. As will be seen, there is much to be said in favor of basic income. Nevertheless, the choice becomes relevant and compelling in light of both the possibility of institutional constraints and the fact that basic income and working-hours regulation address similar normative objectives across a number of dimensions.

Part I of this Article surveys a basic income proposal and explores the parameters of the basic-income idea and how it differs from other welfare-state and tax-and-transfer policies. Part II discusses working-time regulation as it currently exists, explores its history-which will illuminate the sometimes changing normative justifications for working-hours regulation-and examines proposals for extension and reform. Part III constitutes the main analysis of the Article. It investigates the comparability of basic income and working-hours regulation along seven different dimensions: (1) the implications of each proposal for individual liberty, (2) their consequences for equality, (3) the ways they address the problem of technological unemployment, (4) how each policy impacts

27. This approach to studying basic income draws the same distinction and observation made by Ian Shapiro about the study of democracy. He writes, "Normative and explanatory theories of democracy grow out of literatures that proceed, for the most part, on separate tracks, largely uninformed by one another. This is unfortunate, partly because speculation about what ought to be is likely to be more useful when informed by relevant knowledge of what is feasible . ..." IAN Shapiro, The State of Democratic Theory 2 (2009).

28. See, e.g., Rutger Bregman, Utopia for Realists: The Case for a Universal Basic INCOME, OPEN BORDERS, AND A 15-HOUR WORKWEEK (2016). 
the employment relationship, (5) how "universal" each policy is, (6) how economically efficient each proposal is, and (7) each policy's implication for the environment. Following this analysis, the Article concludes.

\section{A BASIC INCOME PRoposal}

Philippe Van Parijs, perhaps the best-known academic advocate of basic income, defines it as "an income paid by a political community to all its members on an individual basis, without means test or work requirement." ${ }^{29}$ As income it is paid in cash, rather than in kind, "without any restrictions as to the nature or timing of the consumption or investment it helps fund." 30 This is a contrast to current welfare policy which, through food stamps or housing grants, effectively provides benefits in kind. Another distinctive feature of this income grant is that it is paid on some regular basis, rather than as a one-time endowment. ${ }^{31}$

A basic income is paid by some political community. However, this entity need not be a nation state. ${ }^{32}$ For example, it could be paid by a sub-national political unit (e.g., Alaska rather than the U.S. Government) or a supra-national political unit (e.g., the European Union). ${ }^{33}$ Furthermore, it need not be paid out of tax revenues. ${ }^{34}$ For instance, financing basic income could be done out of a sovereign wealth fund (e.g., Alaska again, which pays a dividend scheme funded out of part of the return on a diversified investment fund financed by royalties on Alaskan oil fields ${ }^{35}$ ).

Basic income is also paid to "all of its members." ${ }^{36}$ How inclusive the

29. Philippe Van Parijs, Basic Income: A Simple and Powerful Idea for the Twenty-First Century, in Redesigning Distribution: Basic Income and Stakeholder Grants as CORnERstones For an Egalitarian CAPITALism 3, 4 (Erik Olin Wright ed., 2006) [hereinafter REDESIGNING Distribution].

30. Id.

31. Id. For a useful comparison of basic income with a one-time endowment, namely, a socalled "stakeholding" scheme, see Bruce A. Ackerman \& Anne Alstott, Why Stakeholding?, in REDESIGNing Distribution, supra note 29, at 43.

32. Van Parijs, supra note 29 , at 5.

33. Id at 5-6.

34. Id. at 6. On financing, see Charles M. A. Clark, The Economics of Poverty in the United States of America, 4 Oikonomia: J. Ethics \& Soc. Sci. 6 (2005); A. B. Atkinson, Public Economics in Action: The Basic Income/Flat Tax Proposal (1995); Shinji Murakami, The Financial Feasibility of Basic Income and the Idea of a Refundable Tax Credit in Japan, in BASIC Income in JaPAN: Prospects for a Radical Idea in a Transforming Welfare (Y. Vanderborght \& T. Yamamori eds., 2014); Jordi Arcarons et al., Feasibility of Financing a Basic Income, 9 Basic InCOME STUdies 79 (2014).

35. Van Parijs, supra note 29, at 6. See also Michael Wayne Howard \& Karl Widerquist, Alaska's Permanent Fund Dividend: Examining Its Suitability as a Model (2012).

36. Van Parijs, supra note 29. 
definition of "member" or "citizen" is open to some debate. ${ }^{37}$ Some would restrict the benefit to citizens in the strict legal sense. Others argue that "members" should include all legal permanent residents. Another issue is the age level at which recipients should qualify. ${ }^{38}$ Should children or pensioners be entitled to basic income? Often, the answers to these questions depend on the more subsidiary goals of what is desired from a basic income. Suffice it to say that the concept of "citizen," even in its most restricted sense, is a fairly broad category, consistent with basic income's "universal" aspirations. Finally, basic income is paid to each member on an individual basis and does not depend on household size. ${ }^{39}$ That is, there is no downward adjustment in the size of the transfer if, for instance, members are part of a larger household, in recognition of the fact that the per capita cost of living is smaller in larger households. This is one feature that distinguishes basic income from otherwise closely-related proposals for guaranteed minimum income. ${ }^{40}$

Central to the idea of basic income is its claim to universality. ${ }^{41}$ As such, basic income is not conditioned on one's level of income, and rich and poor alike receive it in the same amount. This is another feature that distinguishes basic income from both the guaranteed minimum income and negative income tax proposals. Each of these proposals is means tested: receiving a cash transfer depends on having prior income below some designated threshold. ${ }^{42}$ Although the rich receive transfers, basic income will not make the rich richer since, at least given current tax-and-benefit systems, the relatively rich will be paying both for their own basic income as well as that of the poor. ${ }^{43}$ Furthermore, advocates have pointed out reasons for why it is better for both the poor and the rich to receive basic income. ${ }^{44}$ For one, universality improves take-up rates by removing

\section{Id. at 6 .}

38. Id. at 7.

39. Id. at 8 .

40. Id. at 21 ("[U]nlike most existing guaranteed minimum income schemes, basic income is meant to be strictly individual.").

41. Id. at 8-9.

42. A negative income tax is often specified such that each and every individual is entitled to a "demogrant" of a fixed amount. Id. However, depending on the tax schedule, this will operate as a net benefit, in which case the individual receives a refundable credit, or only as a reduction in income tax paid, in which case the individual receives nothing other than the lower tax liability. Thus, as Van Parijs writes,

In this sense, existing schemes operate ex post, on the basis of a prior assessment, be it provisional, of the beneficiaries' income. A basic income scheme, instead, operates ex ante, irrespective of any income test. The benefit is given in full to those whose income exceeds the stipulated minimum no less than to those whose income falls short of it.

Id. at 9; see also Pertti Honkanen, Basic Income and Negative Income Tax: A Comparison with a Simulation Model, 9 BASIC Income STUD. 119 (2014).

43. Van Parijs, supra note 29, at 9-10.

44. Id. at 10 . 
administrative obstacles that exist under means-tested benefits. ${ }^{45}$ Perhaps more pointedly, universality implies that "there is nothing humiliating about benefits given to all as a matter of citizenship." ${ }^{" 46}$ Thus, universality removes the social stigma from accepting transfers, as well as presumably increasing political support for it. ${ }^{47}$

Just as receiving basic income does not require satisfying a means or income test, it is also not conditioned on any work requirement. ${ }^{48}$ Unlike the Earned Income Tax Credit in the United States or the Working Families Tax Credit in the United Kingdom, receiving basic income does not require the performance of any work. ${ }^{49}$ In fact, basic income does not even require demonstrating a willingness to work nor, as proposed in some participation income proposals, the fulfillment of some broader notion of social contribution, such as employment, education, training, job search, or home care for children or elderly. ${ }^{50}$

\section{A Working-Time Regulation Proposal}

In contrast to basic income, working-time regulation is not a relatively untested policy proposal. In fact, overtime regulation is a central feature of the Fair Labor Standards Act of 1938 (FLSA), the same New Deal act that establishes federal minimum wage standards. ${ }^{51}$ This Part will give a brief overview of the FLSA's overtime provisions, some useful history behind them, and then a discussion of current proposals to amend and expand these provisions.

\section{A. The FLSA's Overtime Provisions}

Section 207 of the FLSA mandates that employers pay their employees oneand-one-half times employees' regular rate of pay for any hours worked in excess of forty in a single week. ${ }^{52}$ There are several features to observe of this requirement. First, note that it does not, strictly speaking, establish a "maximum" number of hours for an employee's workweek.$^{53}$ Rather, an employee may work any number of feasible hours in a workweek, so long as the employer

45. Id.

46. Id.; see also Carole Pateman, Democratizing Citizenship: Some Advantages of a Basic Income, 32 PoL. \& Soc. 89 (2004).

47. See infra Part III.E for a discussion on why this is in fact an assumption about this feature of basic income and one that should be subject to criticism.

48. Van Parijs, supra note 29, at 13-14.

49. Id. at 13 .

50. Id. at 13-14. See also Simon Birnbaum, Should Surfers Be Ostracized? Basic Income, Liberal Neutrality, and the Work Ethos, 10 Pol. PHIL. \& Econ. 396 (2011); Philippe Van Parijs, Why Surfers Should Be Fed: The Liberal Case for an Unconditional Basic Income, 20 PHIL. \& PuB. AFF. 101 (1991).

51. 29 U.S.C. $\S \S 201-219$ (2012).

52. Id. $\S 207$.

53. Marion G. Crain et al., Work Law: Cases and Materials 779 (3d ed. 2015). 
compensates her at a higher rate for hours above forty. ${ }^{54}$ At the same time, the higher costs of paying workers above the forty-hour standard creates a financial incentive for employers to keep work hours below this level and to hire additional workers instead. ${ }^{55}$

Second, note that workers entitled to overtime are owed compensation that is one-and-one-half times their regular rate of pay and not, for example, one-andone-half times the minimum wage.$^{56}$ For workers paid on an hourly basis, the regular rate of pay is simply the hourly wage. ${ }^{57}$ For workers paid on salary, commission, piece rate, or other basis, the "regular rate is computed by dividing the employee's total weekly remuneration for a workweek by the number of hours actually worked during the week." 58

Third, certain "white collar" employees are exempted from the FLSA's overtime provisions. ${ }^{59}$ Although "white collar" is not a phrase used in the FLSA, it is a shorthand, encompassing term for the specific exemptions for executive, administrative, professional, and outside salespersons. ${ }^{60}$ There are several rationales for these exemptions. First, hourly compensation and overtime pay were considered inappropriate or incompatible with the middle- and upper-class status associated with these white collar positions. ${ }^{61}$ Second, such workers were believed to have sufficient autonomy and bargaining power that they did not require protection from the FLSA. ${ }^{62}$ Finally, it was also believed that the nature of this white collar work made it difficult to standardize and spread to other workers. ${ }^{63}$

\section{B. Historical Origins of Working-Time Regulation}

The history of the FLSA's overtime provisions will inform the evaluative discussion that follows in Part III. "Maximum hours labor standards arose from the 'short hours movements' of the late nineteenth and early twentieth centuries. The short hours movements were a major source of worker solidarity and growth of the United States labor movement .... ." ${ }^{94}$ The labor movement's struggle for shorter hours was the expression of a desire to "work less and live more"-a

54. 29 U.S.C. $\$ 207$ (2012).

55. CRAIN ET AL., supra note 53, at 808 .

56. Id. at 779 .

57. Id.

58. $I d$.

59. 29 U.S.C. $\S 213(\mathrm{a})(1)$ (2012).

60. CRAIN ET AL., supra note 53, at 803.

61. Id.

62. Id.

63. Id.

64. Scott D. Miller, Revitalizing the FLSA, 19 Hofstra LAB. \& EmP. L.J. 1, 7 (2001). For more history of the 'short hours movement,' see William A. Mirola, RedeEming Time: Protestantism and Chicago's Eight-Hour Movement, 1866-1912 (2015); and Antony Evelyn Alcock, History of the International Labour Organisation (1971). 
"desire for personal freedom (time) from industrial order, and freedom for home life and cultural matters outside wage and job concerns." 65

Several of the American labor movement's bloodiest and most well-known strikes emerged from the short hours movement. In 1886, Samuel Gompers, leader of the predecessor to the American Federation of Labor, called for a nationwide strike to take place on May 1 of that year. ${ }^{66}$ The objective of the national strike was to achieve a shorter workweek- "ten hours' pay for eight hours' work." ${ }^{67}$ The police violence that occurred during the May 1 strike led to a rally on May 4, 1886, later known as the Haymarket riot or massacre. ${ }^{68}$ During the Haymarket riot, several police officers were killed, and several labor movement activists were later convicted and executed. ${ }^{69}$ Since then, May 1 has been considered the "international" workers' or labor day around much of the world. ${ }^{70}$

Although one initial motive for working-time regulation was shorter hours and greater personal freedom, the onset of the Great Depression, decades after the campaign's initiation and the Haymarket events, created new and additional rationales. ${ }^{71}$ The Depression witnessed a dramatic increase in unemployment, and work-time regulation came to be seen as a solution. By shortening working hours, employers would be forced to hire more workers in order to satisfy demanddriven production requirements. Thus, not only could work-hours regulation create more leisure time for workers, but it could also create more work opportunities for those struggling to find a job. ${ }^{72}$

Scholars and historians appear to agree that the FLSA was only a partial victory for the labor movements' shorter hours objectives. ${ }^{73}$ Although during the

65. Miller, supra note 64.

66. Id. at 12 .

67. Id.

68. Id. at 13 .

69. $I d$.

70. See generally Philip S. Foner, May Day: A Short History of the International WORKERS' HOLIDAY, 1886-1986 (1986).

71. Deborah C. Malamud, Engineering the Middle Classes: Class Line-Drawing in New Deal Hours Legislation, 96 MicH.L. REV. 2212, 2223 (1998) (explaining that protecting workers' health was the primary objective of pre-New Deal hours regulation while job creation or "work-spreading" was the central policy goal of the New Deal's hours policy); Juliet Schor, Worktime in Contemporary Context: Amending the Fair Labor Standards Act, 70 CHI.-Kent L. REV. 157, 163 (1994) ("When the Depression hit, worktime reduction, or worksharing, became a very popular solution.").

72. Sang-Heon Lee et al., Working Time Around the World: Trends in Working Hours, Laws and Policies in a Global Comparative Perspective 9 (2007).

73. See, e.g., Miller, supra note 64, at 24 ("The FLSA linkage of wages with hours as an 'either/or choice' signaled an ideological and rhetorical shift in the debate regarding labor and capital.”); Schor, supra note 71, at 164 ("“T] he passage of the FLSA showed that 'the forces behind share the work and the continuation of the progressive shortening of the hours of labor had been routed."') (quoting Benjamin Kline Hunnicutt, Work Without End: Abandoning Shorter 
Great Depression the labor movement supported worktime reductions, both as a way to promote greater leisure and reduce unemployment, other social interests had alternative solutions. For business interests, another way to address unemployment was to increase consumption. ${ }^{74}$ Increased productivity can potentially increase leisure, as basic needs can be more easily satisfied; however, it can also be used to create new goods and services, the increasing demand for which would fuel growth in employment.

As told by several scholars, these competing visions shaped the story of the passage of the FLSA. According to Professor Juliet Schor, "The 30-hour week was the primary unemployment measure advocated by the American Federation of Labor." 75 Legislative support for this vision came in 1933, when the Senate passed Hugo Black's worktime reduction bill, which mandated thirty-hour workweeks. ${ }^{76}$ Initially supportive of such measures, President Roosevelt reversed himself as business pressures mounted. ${ }^{77}$ The resulting FLSA only weakly reflected labors' concerns: It did not set maximum hour limits, but only established a financial disincentive for longer hours; it did not address vacations or other time off; did not institute any provisions for future changes in productivity or working time; and omitted a substantial fraction of the workforce from its coverage. ${ }^{78}$

\section{Proposals for Reform}

It will not be necessary to give a concrete proposal for reforming workinghours regulation. As will be made clearer in the subsequent analysis, what is important is that reform increases workers' opportunity for leisure, contributes to the creation of additional employment, and, despite the reduction in hours worked, it entails little or no reduction in pay, especially for workers at the bottom of the income scale. There are several methods for accomplishing these objectives. As will be illustrated, some particular concerns call for more specific prescriptions.

To give shape to the discussion, this Article will summarize the recommendations of Professor Schor. ${ }^{79}$ Professor Schor has been an articulate advocate for reforming and amending the FLSA. She advocates several important changes. Her first proposal is to reduce the standard forty-hour workweek (she envisions instead a thirty-two-hour workweek) and eliminate premium pay for overtime work. ${ }^{80}$ In place of premium pay, she would implement a system of compensated time, or "comp time," which would give employees time off at a

HOURS FOR THE RigHT TO WORK 247 (1988)).

74. Schor, supra note 71 , at 162-63.

75. Id. at 163 .

76. Id.

77. Id.

78. Id. at 164 .

79. These proposals can be found in Schor, supra note 71, at 164-71.

80. Id. at 167-68. 
rate of time and a half for overtime. ${ }^{81}$ Comp time is already an established practice in the public sector, where it reflects a policy preference for leisure over consumption. ${ }^{82}$ Second, Schor proposes that employers allow workers to trade income for time. ${ }^{83}$ For instance, employees could forego the opportunity for annual raises or could reduce current compensation in exchange for "shorter daily hours, the 'buying' of vacation days, a four-day week, ten-month schedules and sabbaticals." 84

A third area of reform would be to tighten, or even eliminate, the so-called "white collar" exemptions in the FLSA. ${ }^{85}$ Schor proposes covering all salaried employees, but allowing employers to exempt some of these employees (the "top $20 \%$ " of the workforce), while requiring them to designate an alternative standard of weekly and annual hours for this group (she suggests that employers be free "to set any standard below 60 hours a week and 2880 hours per year"). ${ }^{86}$ This proposal would reduce overtime work for salaried employees as well as employer abuse of that designation, while also recognizing the greater flexibility required for high-level, white-collar employees. ${ }^{87}$ Schor also proposes legislation to sanction employers who discriminate against employees who express preferences or choose to work shorter hours. ${ }^{88}$ Finally, to forestall any reduction in pay, Schor would increase the minimum wage. ${ }^{89}$

\section{A COMPARATIVE Evaluation of BAsic InCOME AND WORKING-TIME REGULATION}

\section{A. Liberty}

One of the main arguments in favor of basic income is that it enhances individual liberty. Van Parijs is perhaps the most articulate representative of this perspective. He argues that "a defensible liberal conception of social justice ... must maximin ... people's real freedom, that is, the means they require for the pursuit of their conception of the good life, whatever that is." ${ }^{90}$ Van Parijs further argues that "a defensible liberal theory of justice, that is, one that is truly committed to an equal concern for all and to nondiscrimination among conceptions of the good life, does justify, under appropriate factual conditions,

81. Id. at 167 .

82. CRAIN ET AL., supra note 53, at 780.

83. Schor, supra note 71 , at $168-70$.

84. Id. at 168 .

85. Id. at $170-71$.

86. Id. at 170 .

87. Id.

88. Id. at 171 .

89. Juliet B. Schor, The Overworked American: The UneXPected Decline of Leisure 151 (1991).

90. Van Parijs, supra note 50, at 103. "By 'maximin' I mean that a strong priority is being given to the real freedom of those with the least amount of real freedom." Id. 
a substantial unconditional basic income." ${ }^{91}$ In this section, this Article summarizes Van Parijs's liberal theory of basic income, and then compares effects of basic income on individual liberty with effects of working-hours regulation.

Van Parijs takes as his starting position the liberal theory of John Rawls. ${ }^{92}$ According to Rawls's Difference Principle, socioeconomic advantages should be maximinned, that is, should be "distributed in such a way that the least advantaged end up with at least as many advantages as the least advantaged would end up with under any alternative arrangement. ${ }^{93}$ But what is among the set of "socioeconomic advantages" that should be maximinned? Van Parijs first notes that if the Difference Principle were to maximin only income, then an unconditional basic income may not be justified, since "some sort of conditional transfer system would, in many circumstances, perform better than an unconditional basic income. ${ }^{" 94}$ However, Van Parijs, as well as Rawls, mention several other forms of socioeconomic advantages, including "wealth," 95 the "powers and prerogatives attached to social positions," self-respect." 97 Like basic income and unlike ordinary income, wealth is unconditional and is not (directly) a return for labor or capital services. Basic income therefore promotes the maximinning of wealth. ${ }^{98}$ Furthermore, because an unconditional basic income reduces an individual's dependency on paid employment, it "confers upon the weakest more bargaining power in their dealings with both potential employers and the state." $" 99$ This more substantial bargaining power gives individuals a stronger likelihood of securing for themselves greater powers and prerogatives attaching to their social positions. Finally, a welfare system that requires a means test or the demonstration of an inability to work forces individuals to show themselves "inadequate." 100 This demonstration tends to stigmatize, humiliate, and otherwise undermine the recipients' self-respect. An unconditional basic income-received by all, regardless of income, requiring neither a willingness nor an ability to work - supposedly avoids these stigmatizing features of the modern welfare state and therefore promotes self-respect.

Although not central to his Rawlsian defense of basic income, it is clear that a-perhaps the - central appeal of basic income for Van Parijs (and others) is the way it can enhance leisure for certain individuals. ${ }^{101}$ His motivating example,

91. Id. at 102 .

92. Id. at 103 .

93. Id. at 104.

94. Id.

95. Id.

96. Id. at $104-05$.

97. Id. at 105 .

98. Id. at 104 .

99. Id. at 105 .

100. Id.

101. See id. at 108-12. 
included in the introduction and title of the article in which he makes this case, is the "lazy surfer." 102 There are some individuals who prefer to surf all day and find paid work in the market to be too onerous. ${ }^{103}$ Other kinds of individuals would fall into a similar category. For example, persons whose only joy is producing artwork for which there is no public interest or purchasing market. Although Van Parijs' liberal argument for basic income does not include leisure in the index of primary goods, ${ }^{104}$ a basic income that distributes wealth and confers bargaining power certainly makes such lives possible. It is clear that providing a means of sustenance to those who would prefer such lives of leisure is the motivating force behind Van Parijs' argument. Thus, maximinning leisure is not a justification for basic income, but it is a crucial implication of the socioeconomic advantages that should be maximinned.

Based on this interpretation of the Difference Principle, Van Parijs concludes that "one should introduce a wealth-distributing, power-conferring, self-respectpreserving unconditional basic income, indeed, that one should introduce such an income at the highest sustainable level." ${ }^{105}$ However, Van Parijs does address one major objection: Basic income discriminates in favor of individuals who have a particular-even expensive- taste for leisure. ${ }^{106}$ When moving to a basic income scheme, the welfare of those who have small material needs and prefer a lot of leisure are made substantially better off than those who prefer to work and have a high level of material needs. ${ }^{107}$ Under some standard interpretations, basic income therefore represents an-illiberal-bias in favor of the "lazy." 108

Van Parijs considers several possible answers to this objection before settling on the following reasoning. ${ }^{109}$ This reasoning is derived from Ronald Dworkin's notion of equality of external resources. ${ }^{110}$ Individuals require certain resources that are external to their talents (for instance, land) to achieve their preferred income or living standards. ${ }^{111}$ These external resources could be allocated equally among all individuals - and this would constitute one nondiscriminatory means of allocating them. ${ }^{112}$ But different individuals-indeed those who prefer more or less leisure-might want more or fewer external resources to achieve their preferred allocation of income and leisure. ${ }^{113}$ Those who prefer leisure may be

102. See id. at 101-02, 130-31.

103. See id. at 108-12.

104. For reasons why Van Parijs does not include leisure as a primary good, see $i d$. at 108-15.

105. Id. at 105 .

106. Id.

107. See id.

108. Id. This is sometimes referred to as the 'exploitation' of the harder-working members of society. For a good discussion of Van Parijs' argument, see Stuart White, Liberal Equality, Exploitation, and the Case for an Unconditional Basic Income, 45 POL. STUD. 312 (1997).

109. Van Parijs, supra note 50, at 108-12.

110. Id. at 112 .

111. Id.

112. Id.

113. Id. 
perfectly willing to trade external resources with those who prefer work in exchange for income. ${ }^{114}$ Van Parijs then reasons, "There is a nonarbitrary and generally positive legitimate level of basic income that is determined by the per capita value of society's external resources and must be entirely financed by those who appropriate these resources." 115 This reasoning, according to Van Parijs, justifies a neutral, nondiscriminatory policy supporting basic income. ${ }^{116}$ Van Parijs concludes by clarifying two points that his justification raises: "[W]hat counts as external resources, and how is their value to be determined?" 117 This discussion need not detain us, and the reader can consult his argument in further detail elsewhere. ${ }^{118}$

There is no doubt that a basic income would have a salient impact on the amount of leisure that a significant number of the population would enjoy. But how would it compare with the impact of working-time regulation? The first thing to acknowledge about the basic income proposal is that even if the impact would be significant (along some dimension), it would largely be confined to the lowest-paid workers in the economy. ${ }^{119}$ Because a basic income would provide at most a subsistence-level income to everyone, ${ }^{120}$ only those individuals who earn subsistence-level incomes or lower would have either the option not to work or the bargaining power to secure a more favorable work-leisure trade-off with employers. All individuals above the subsistence level would see little change in the possibility of enjoying more leisure. ${ }^{121}$

In contrast, working-time regulation would affect a substantially larger proportion of the population. Not just subsistence-level workers, but large sections of middle-class workers would also be affected by working-time regulation that limited the number of work hours. This would be particularly true if regulatory reform sought to increase salary thresholds and tighten the exemptions currently applied to white-collar workers. ${ }^{122}$ If one then had to choose between policies based on a liberty-enhancing effect on the ability of individuals to pursue greater leisure, working-time regulation is preferred to basic income.

One might object that working-time regulation would be less flexible or

114. Id.

115. Id.

116. Id.

117. Id. at 113 .

118. Id. at 113-17.

119. Elizabeth Anderson, What is the Point of Equality?, 109 EтніCs 287, 298-99 (1999) (explaining the level of basic income would have to be fairly low to sustain an incentive to work and provide the money required to fund it).

120. $I d$.

121. For example, in a setup with a $33.33 \%$ flat tax and a $\$ 6000$ basic income, the "break-even point" would be on a yearly salary of $\$ 18,000$ - that is, everyone with a salary above $\$ 18,000$ would be a net-contributor. Naturally, basic income is often framed as an instrument to counter poverty. See generally Karl Widerquist, Independence, Propertylessness, and Basic InCOME: A TheORY of Freedom AS THe Power to SAY No (2013).

122. See supra notes 85-89 and accompanying text. 
adaptable to individual needs than basic income. Regulation unfortunately often comes in a one-size-fits-all form. If this is the case, working-time regulation would impose upon some workers leisure time when they would in fact prefer to work. In contrast, basic income places no restrictions on individuals' ability to pursue paid work. ${ }^{123}$ Nor does basic income distort individual decisions on the margin through means testing or administratively-burdensome or stigmatizing work requirements. ${ }^{124}$ Is the greater coverage of working-time regulation worth the potential loss of individual choice? This must be a particularly important concern if a policy that promotes leisure is based on the imperative of enhancing individual liberty.

In fact, working-time regulation as it exists now-and even more as it is envisioned in reform proposals - gives generous scope to individual preferences. As previously mentioned, the current incarnation of the FLSA does not impose maximum working hours. ${ }^{125}$ Rather, it requires additional compensation for hours worked beyond the designated forty per week. ${ }^{126}$ Thus, the FLSA does allow flexibility for employees' different preferences over work and leisure to find expression under the regulation. Although many reform proposals seek to abolish overtime compensation, these proposals usually come with alternative means of accommodating employees' various work-leisure preferences. For instance, Schor proposes replacing overtime compensation with "comp time" - the ability to earn additional time off for overtime hours worked. ${ }^{127}$ Workers could also trade-off compensation for other forms of time off — vacation, a shorter work year, or even a shorter working career via sabbatical time. All of these possibilities allow for the expression of differing worker preferences for leisure-and they would establish more opportunities than exist under the current FLSA.

To avoid paternalism, we should permit workers latitude to divide their time between work and leisure. Yet one should also recall the-very likely-socially determined nature of work preferences. ${ }^{128}$ Traditional economic theory posits that individual utility depends only on absolute consumption. ${ }^{129}$ But recent theory and evidence acknowledges that individual utility also depends on relative consumption-how much a person consumes depends on the consumption choices of those around her. ${ }^{130}$ For instance, consider the following example.

123. See generally Van Parijs, supra note 50.

124. See id. at 105.

125. See supra Part II.B.

126. Handy Reference Guide to the Fair Labor Standards Act, U.S. DEP'T OF LABOR (Sept. 2016), https://www.dol.gov/whd/regs/compliance/hrg.htm [https://perma.cc/QQW7-RFUR].

127. Schor, supra note 71, at 167.

128. See, e.g., Samuel Bowles, Endogenous Preferences: The Cultural Consequences of Markets and other Economic Institutions, 36 J. ECON. LiT. 75 (1998) (reviewing the economics literature on the endogenous formation of preferences).

129. Amitava Krishna Dutt \& Benjamin RadclifF, Happiness, Economics and Politics: TOWARdS A Multi-DisciplinARY APPROACH 147 (2009).

130. See generally Samuel Bowles \& Yongjin Park, Emulation, Inequality, and Work Hours: Was Thorstein Veblen Right?, 115 ECON. J. F397 (2005); Robert H. Frank, Positional Externalities 
Suppose you can live in a 4000-square-foot house but everyone else lives in 6000 -square-foot houses. But you can also choose to live in a 3000 -square foot house while everyone else lives in 2000-square-foot houses. ${ }^{131}$ Facing this hypothetical scenario, most people choose to live in the smaller house, which makes them better off in terms of relative consumption yet makes them worse off in absolute terms. ${ }^{132}$ Thus, others' consumption decisions matter to one's own.

While giving a more accurate view of individual choice, relative-consumption behavior can unfortunately be inefficient from an economic point of view, leading to losses in social welfare. ${ }^{133}$ Specifically, a desire to "keep up with the Joneses" ${ }^{\prime 34}$ will cause people to spend more on consumption than they might otherwise. This is wasteful "arms race" 135 behavior because, since everyone does it, it does not change relative-consumption rankings. People would be better off if everyone reduced consumption. Typically, because of the problem of coordinating behavior and enforcing commitments, reducing consumption is difficult or impossible without the intervention of government or some other collective organization. ${ }^{136}$

Relative-consumption behavior also applies directly to the work versus leisure choice. ${ }^{137}$ From a desire to keep up with the consumption standards of others, individuals will allocate more time to work than leisure than they otherwise would. ${ }^{138}$ Although longer working hours generates more income and therefore more consumption, it lowers welfare because it is wasteful, "positional" consumption. This inefficiency creates a scope for public policy. Absent the relative-consumption effect, individuals would prefer to work fewer hours. Thus,

Cause Large and Preventable Welfare Losses, 95 AM. ECON. REV. 137 (2005).

131. This hypothetical is drawn from Frank, supra note 130, at 137.

132. Id.

133. Id. ("The disparity [in relative consumption] gives rise to expenditure arms races focused on positional goods - those for which relative position matters most. The result is to divert resources from nonpositional goods, causing welfare losses.”).

134. Bowles \& Park, supra note 130, at F398.

135. In addition to analogizing "relative consumption externalities" to an "arms race," they can also be described as "positional externalities." See Robert H. Frank, Should Public Policy Respond to Positional Externalities, 92 J.PUB. ECON. 1777 (2008) ("Before addressing whether the harm caused by positional externalities should be mitigated by legislation, it is useful to review the conditions under which such externalities can be expected to cause harm in the first place. Those conditions are precisely analogous to the ones that make military arms races between equally matched rival nations wasteful."). On the implications for positional externalities and the law generally, see Richard H. McAdams, Relative Preferences, 102 YALE L.J. 1 (1992).

136. Relative consumption externalities can therefore be considered among the class of "market failures" for which government intervention is justified in economic theory. See Frank, supra note 130, at 140 (writing that the economics "profession has incorporated numerous other forms of market failure into its arsenal of policy recommendations").

137. For a study of relative consumption behavior in the case of the labor-leisure trade-off see generally Bowles \& Park, supra note 130.

138. Id. at F399-400. 
reducing working time can increase social welfare. ${ }^{139}$ More importantly, although work-leisure preferences vary across individuals-requiring flexibility in the regulation policy - the fact of relative-consumption effects justifies the reduction of working time for all workers. ${ }^{140}$ This addresses to a significant extent the onesize-does-not-fit-all objection.

The conclusion is that while basic income would certainly expand the scope for leisure in society, this opportunity will only be available to some of the lowest paid workers. Basic income will do nothing to increase availability of leisure time for broad sections of middle- and even upper-class workers. On the other hand, working-time regulation can do much more to make the choice of leisure time a more tangible option for many of these workers. Working-time regulation can therefore do better than basic income in expanding freedom-literally making free time more abundant for more people.

\section{B. Equality}

Another lauded benefit of basic income is that it can have a salient effect on the reduction of income inequality. Set at a high enough level, basic income could end poverty at a stroke. ${ }^{141}$ The tax financing of basic income can be made significantly progressive. ${ }^{142}$ And because the transfer is lump sum, basic income can have a quite significant redistributive effect. ${ }^{143}$ Thus, as basic-income advocates have pointed out, the fact that rich and poor alike receive basic income does not mean that "a basic income would make both rich and poor richer than before," 144 nor that a basic income would increase income inequality. For example, if basic income were funded through a progressive income tax, "it is clear the comparatively rich would need to pay both for their own basic income and for much of the basic income of the comparatively poor." ${ }^{145}$ Financing basic income through such a mechanism can make it significantly redistributive. ${ }^{146}$ Significantly, however, basic income can be financed through alternative means in ways that make its redistributive impact slight. ${ }^{147}$ Finally, how redistributive a basic income is also depends on its level. ${ }^{148}$

139. Id. at F408-10 (discussing the policy implications of their research findings).

140. Id.

141. Matthews, supra note 2 (as indicated in the title of his article).

142. Richard Parncutt, Eliminate Poverty with Universal Basic Income and Flat Income Tax (UBI-FIT) (2011), PARNCUTT.ORG, http://www.parncutt.org/BIFT1.html [https://perma.cc/M4WGW2GE].

143. Van Parijs, supra note 29, at 9.

144. Id.

145. Id.

146. Id. at 6 .

147. Id. ("Redistributive taxation, however, need not be the only source of funding. Alaska's dividend scheme ... is funded out of part of the return on a diversified investment fund which the state built up using the royalties on Alaska's vast oil fields.").

148. Id. at 10 ("The immediate impact on the income distribution can then be kept within 
But just how egalitarian is basic income? Does it achieve everything that an egalitarian would desire? And how does the egalitarian impact of a basic income compare to that of working-time regulation? In this section, this Article argues that basic income has significant shortcomings in addressing egalitarian concerns. These shortcomings include not only failing to deliver everything that an egalitarian might want, but also undermining key egalitarian objectives. In contrast, working-time regulation does much better at satisfying egalitarian principles.

Note first that if the sole purpose of basic income were to reduce poverty or maximin income, it would clearly fail. As already admitted, some conditional income transfer program could probably achieve this objective much more effectively. ${ }^{149}$ Hence, the deeper case for basic income rests on an argument about maximinning, in Van Parijs' version, "real freedom." 150 Yet even this more sophisticated argument is subject to criticism. As described in the previous section, this particular philosophical defense of basic income has its roots in John Rawls' political philosophy and in particular with his principles of equality. ${ }^{151}$ Elizabeth Anderson refers to this conception of equality as "luck egalitarianism" or "equality of fortune." 152 She contends that this conception of equality fails a basic test that any egalitarian philosophy should meet: "that its principles express equal respect and concern for all citizens." 153

Anderson argues that luck egalitarianism fails this test in three ways. ${ }^{154}$ The first two directly implicate our evaluation of basic income. ${ }^{155}$ The first objection is that luck egalitarianism deprives some citizens of enjoying what she calls "the social conditions of freedom" on the grounds - incorrect, she argues - that they are at fault for losing them. ${ }^{156}$ According to luck egalitarianism, the "fundamental aim of equality is to compensate people for undeserved bad luck-being born with poor native endowments, bad parents, and disagreeable personalities, suffering from accidents and illness, and so forth." ${ }^{" 157}$ But following this principle to its logical conclusion can lead to some disturbing results. Anderson's strongest example is dependent caretakers. ${ }^{158}$ These include individuals, most often women, who choose to care for others (children, the aged, or the ill or infirm) but who

fairly narrow bounds for a modest basic income. But the higher its level, the higher the average rate of income tax and therefore the greater the redistribution from the comparatively rich to the comparatively poor.”).

149. See supra Part III.A.

150. Van Parijs, supra note 29, at 24.

151. Anderson, supra note 119, at 290.

152. Id. at 289 .

153. Id.

154. Id.

155. Id.

156. $I d$.

157. Id. at 288 .

158. Id. at 297 ("Dependent caretakers and their children face special problems under equality of fortune."). 
thereby render themselves dependent on others, such as a (male) wage earner or on welfare payments. ${ }^{159}$ According to luck egalitarianism, even if these dependent caretakers live in destitution, they are not entitled to public assistance because they have voluntarily chosen these roles. ${ }^{160}$

In Anderson's view, this result evidences a failure to express equal concern for all of society's members. ${ }^{161}$ In fact, she uses Van Parijs' case for basic income as an illustration of this failure. ${ }^{162}$ Because basic income is awarded to all unconditionally, "[1]azy, able-bodied surfers would be just as entitled to that income as dependent caretakers or the disabled." 163 In order to not destroy work incentives and thereby the (potential) tax base for a basic income, the level of basic income would have to be kept (possibly extremely) low. ${ }^{164}$ Such a low basic income might satisfy surfers who must support only themselves and may be content with extremely modest living arrangements. ${ }^{165}$ But it may be inadequate for dependent caretakers who must take care not only of themselves but also others, or the disabled who have special expenses. ${ }^{166}$ As Anderson concludes, "Van Parijs's proposal effectively indulges the tastes of the lazy and irresponsible at the expense of others who need assistance." ${ }^{.67}$ Thus, basic income does not evince an equal respect or concern for members of society.

A second objection that Anderson makes is that luck egalitarianism grounds the basis for citizens' claims on the public in the observation that some individuals are inherently inferior to others in terms of their attributes, talents, and other characteristics. ${ }^{168}$ "Thus, its principles express contemptuous pity for those the state stamps as sadly inferior and uphold envy as a basis for distributing goods from the lucky to the unfortunate." 169 Anderson does not illustrate this criticism with basic income, but it is simple to draw that connection. Van Parijs' paradigmatic beneficiary of basic income is the "lazy surfer." 170 And basic income would no doubt constitute a substantial enhancement in "real freedom" for such individuals, and would make possible a fulfilling and meaningful life that would not be possible in the absence of basic income. Another example is persons who desire little more than to create art, but that cannot support themselves as artists because their work remains unknown or unpopular. For these persons, basic income would also make possible lives of meaning previously available only to others.

159. Id.

160. Id.

161. Id. at 298 .

162. Id. at 299.

163. Id.

164. Id.

165. $I d$.

166. Id.

167. Id.

168. Id. at 289 .

169. Id.

170. Van Parijs, supra note 50, at 101-02, 130-31. 
But if the lazy surfer is the paradigmatic beneficiary of basic income, is it the representative one? Many-if not most — recipients of basic income are unlikely to be lazy surfers or starving artists. Instead, unlike these convention-crashing iconoclasts, most recipients of basic income would prefer to become "productive" and "contributing" members of society. What would basic income mean to them? Unfortunately, for these individuals, basic income may well have the effect of increasing, rather than decreasing, inequality.

Consider Anderson's humorously hypothetical, but illustrative, example of the communicative effects of public compensation:

To the stupid and untalented: Unfortunately, other people don't value what little you have to offer in the system of production. Your talents are too meager to command much market value. Because of the misfortune that you were born so poorly endowed with talents, we productive ones will make it up to you: we'll let you share in the bounty of what we have produced with our vastly superior and highly valued abilities. ${ }^{171}$

For many proponents, basic income is supposed to avoid these more-or-less explicit or implicit judgments because of its universality. ${ }^{172}$ This particular feature of basic income will be discussed in more detail below. ${ }^{173}$ But it is hard to imagine basic income not having the judgmental effects Anderson describes. Although all citizens receive basic income, there would be little doubt about who would be the net beneficiaries and the net contributors of the scheme. Thus, on the principles underlying basic income, "People lay claim to the resources of egalitarian redistribution in virtue of their inferiority to others, not in virtue of their equality to others." ${ }^{\prime 174}$ By simply giving cash to the poor, basic income in effect tells net beneficiaries that they have nothing to offer society. Basic income is thus a kind of bread and circuses for the twenty-first century.

Rather than basic income, net beneficiaries may well prefer the kinds of public goods and specific assistance traditionally associated with the welfarestate. Most specifically in this case, these goods would include those such as education, vocational training, unemployment insurance, and so forth. ${ }^{175}$ Such goods make possible the integration of individuals into the normal and expected practices of society. Unlike basic income, the justification for these goods is grounded in equality: They recognize the possible contributions of all members of society and equip or sustain them to be equal (in some measure) participants. Eduardo Porter nicely summarizes this sentiment:

$[R]$ eplacing everything in the safety net with a check would limit the scope of government assistance in damaging ways. Say we know the choice of neighborhood makes a difference to the development of poor

171. Anderson, supra note 119 , at 305 .

172. See generally id.

173. See infra Part III.E.

174. Anderson, supra note 119, at 306.

175. Id. at 313 . 
children. Housing vouchers might lead them to move into a better one.

A monthly check would probably not. ${ }^{176}$

In contrast to basic income, the effects of working-hours regulation are substantially more egalitarian. First, working-hours regulation integrates work and leisure by providing more opportunities for free time to those in paid employment. This is in contrast to basic income, which is premised on and engenders the potential division of the population into working and nonworking. Working-time regulation makes leisure more widely available, rather than confining it to those who work at a subsistence level. Thus, all get to enjoy leisure. The rich already have leisure-or work in professions that are intrinsically rewarding. And working-time regulation increases the leisure-time opportunities for both the poor and middle class. Further, as will be discussed subsequently, working-hours regulation can increase employment opportunities and makes work more widely abundant as well. In sharp contrast to basic income, therefore, working time regulation ameliorates rather than exacerbates the basic social division between working and nonworking populations.

Working-time regulation has at least two other egalitarian effects worth mentioning. The first is that it can reduce gender inequalities. Although women have made significant advancement by entering into more careers and professions, they lag behind men in pay. ${ }^{177}$ As has also been documented, women still tend to do more of the housework at home than do men. ${ }^{178}$ These two facts are related. Sharing more of the household burden limits women's participation in the market economy. These limits make it more difficult for women to advance in their careers or undertake more demanding professions. Indeed, countries with shorter workweeks rank highly in terms of gender equality. ${ }^{179}$ In particular, government-funded paid paternity leave- which certainly can be included as kind of working-time regulation-can make a salient difference. In countries with these policies, men that take advantage of them do more domestic work than otherwise. ${ }^{180}$

It seems likely that if more free time allows men to share more of the household work, then working-time regulation will reduce gender inequality. ${ }^{181}$ To be clear, the gender equality effects are uncertain. For instance, Juliet Schor recognizes that although her proposals "are gender-neutral," "[w]ithout change

176. Porter, supra note 10.

177. According to the OECD 2014 Database, the average 'gender wage gap' in OECD countries was $15.46 \%$, and $17.91 \%$ in the United States. Gender Wage Gap, ORGANISATION FOR ECONOMIC CO-OPERATION AND DEVELOPMENT, https://www.oecd.org/gender/data/genderwagegap. htm [https://perma.cc/MEB8-46TM] (last visited Feb. 10, 2017).

178. For comprehensive studies of the relation between gender-based wage and work inequality, see Francine D. Blau, et AL., Gender, Inequality, And Wages (2013) and Lynn Prince Cookie, Gender-Class Equality in Political Economies (2011).

179. Id.

180. $I d$.

181. CoOKIE, supra note 178 , at 212-13. 
in underlying gender roles ... women will be more likely to take advantage of them." 182 The effect will be only to reproduce existing gender inequalities. But "[i]f men take considerably more responsibility for children and housework-as many now say they want to- then they too will want to opt for working patterns that are compatible with family duties." ${ }^{183}$ This ambiguity is one reason the reform of working-time regulation should take the form, in at least some amount, of parental leave including some mandatory portion for fathers. Thus the form of policy can itself encourage a shift in gender roles.

There is also an association between income inequality and the length of working hours. The previous section discussed the problem of relativeconsumption effects: Conspicuous consumption-keeping up with the Joneses - causes people to spend more time working than enjoying leisure. ${ }^{184} \mathrm{In}$ fact, this effect is stronger when income inequality is higher-when the Joneses become even richer than the rest of us. As the economists Samuel Bowles and Yongjin Park have shown, "Data on work hours in ten countries over the period 1963-98 show that greater inequality is indeed associated [with] longer work hours." 185 As also discussed previously, work-time regulation can be a way to counter this welfare-reducing effect of inequality.

There is a concern that many poor workers would be unable to take advantage of working-time regulation. "The poorest third would work just as many hours as ever-or more, as more work became available ...."186 Those who gain free time would be mostly middle class. This is why it is essential, as mentioned previously, that further reductions in working time come with little or no loss in pay. ${ }^{187}$ There are several methods to achieve this. ${ }^{188}$ Perhaps the most straightforward is an increase in the minimum wage. As Schor explains, "While only a limited fraction of workers receive the minimum, when it rises, it creates upward pressure on those wages which are somewhat higher." ${ }^{" 189}$ It is no accident that the FLSA includes both wage and hour regulations. ${ }^{190}$ Such measures ensure that workers in the lower scales of the income distribution enjoy all of the benefits of productivity growth-both in wages and in free time.

Furthermore, working-time regulation by itself can have egalitarian effects. If working-time regulation creates more middle-class jobs-more on this in the

182. SCHOR, supra note 89 , at 151.

183. Id.

184. Id.

185. Bowles \& Park, supra note 130, at 397.

186. SCHOR, supra note 89 , at 150.

187. See supra Part II.C.

188. Perhaps the most effective way to maintain or increase wages at the bottom of the income distribution is greater coverage in collective bargaining. However, because unions have found it difficult to increase their bargaining influence beyond their immediate membership - currently around six percent of the private workforce - this route presents a challenge. Minimum wage legislation, discussed shortly, has more immediate promise.

189. SCHOR, supra note 89 , at 151.

190. Miller, supra note 64 , at 3. 
next section-it will create opportunities for lower-paid workers to move up in the income distribution. ${ }^{191}$ This effect will reduce inequality. But a lower supply of low-wage labor will also create pressure for employers to raise wages to fill job vacancies. ${ }^{192}$ And this second effect will also reduce income inequality. Third, both rising wages and an increased number of jobs will reduce unemployment and increase labor-force participation. Because unemployment and underemployment are important drivers of inequality, this third set of effects will reduce income inequality. ${ }^{193}$ Most critically, because these effects increase participation of the lowest earners in paid work, the consequences are much more egalitarian - in the deeper, social and cultural sense just discussed-than is the case with basic income.

To summarize, whatever egalitarian effects of basic income on economic inequality, it may well be miniscule in terms of a broader sense of social and political inequality. In contrast, working-time regulation will not only have salient, mitigating effects on economic and gender inequalities, but it fosters broader participation in the economy and society that reduce these same, deeper social inequalities.

\section{Technological Unemployment}

Many proponents of basic income favor it because it addresses a possible impending social dilemma: the creation of mass unemployment because of changes in technology. In this view, technology is creating (or will create) massive disruption in the work place, potentially abolishing the need for employed work. ${ }^{194}$ But this change presents an enormous social problem: what to do with all of the unemployed people? The answer, according to some, is basic income, which provides a guaranteed means of existence independent of paid

191. Economic studies of the effects of working-hours regulation on unemployment rates are ambiguous. See, e.g., Arie Kapteyn et al., The Myth of Worksharing, 11 LAB. Econ. 293, 293 (2004) (reviewing the "most pertinent theoretical and recent empirical contributions to the literature" and finding that "a positive direct effect on employment of a reduction of working hours" but that "taking into account indirect effects, in particular the upward effects on wages, [they] find that the long-run effect becomes small and insignificant"); Jennifer Hunt, Has WorkSharing Worked in Germany?, 114 Q. J. ECON. 117 (1999) (finding for Germany that in response to a one hour fall in standard hours, employment rose by 0.3-0.7 percent).

192. Most studies do find a positive wage effect from working-hours regulation. See, e.g., Hunt, supra note 191; Pedro S. Raposo \& Jan C. van Ours, How Working Time Reduction Affects Jobs and Wages, 106 ECON. LeTTERS 61 (2010).

193. As sociologists and economists frequently observe, unemployment and lower labor force participation are themselves important determinants of income inequality. See, e.g., LANE Kenworthy, Egalitarian Capitalism: Jobs, Income, and Growth in AfFluent Countries (2004).

194. Erik Brynjilfsson \& Andrew McAfee, Race Against the Machine 6-7 (2012); P. CAHUC ET AL., LABOR ECONOMICS 627-76 (2014). 
employment. ${ }^{195}$ It is perhaps not surprising that the most vocal advocates of this particular argument in favor of basic income are associated with Silicon Valley. ${ }^{196}$

In response to this argument, it is first worth pointing out that the prospect of technological unemployment may be a nonproblem. How much technology is changing productivity and employment is a matter of considerable debate. Indeed, according to some prominent economists, the rate of productivity growth has slowed down, almost to a standstill. ${ }^{197}$ If this is true, technological change is unlikely to produce massive unemployment. Low productivity growth creates social challenges of its own, including the ability to reduce income inequality. Basic income may still have some useful policy purpose in this case, but addressing mass unemployment is not one of them. In this section, this Article focuses on that particular problem.

Let's assume for the sake of discussion that massive, technology-induced unemployment is a serious problem. Basic income, under a kind of luckegalitarian rationale, would seem to be the perfect solution. ${ }^{198}$ Technology has rendered large numbers of people unemployable, for reasons that are completely beyond their control. Basic income would give such individuals a means of sustaining themselves, and this is justified in view of the fact that they are "victims" of brute luck.

But is basic income really the perfect solution to mass unemployment? Consider again working-hours regulation. One early rationale for hours regulation-and a continuing one, especially in light of the mass-unemployment argument - is that it can reduce unemployment. ${ }^{199}$ By reducing the number of hours any individual employee can work, employers will find it necessary to hire additional employees to meet the shortfall in production. ${ }^{200}$ Thus, hours regulation

195. Martin Ford, Rise of the Robots: Technology and the Threat of a Jobless FUTURE 178-80 (2015).

196. Annie Lowrey, The Anti-Poverty Experiment That Could Fix America's Broken Welfare System, N.Y. MAG. (May 1, 2016), http://nymag.com/daily/intelligencer/2016/04/first-universalbasic-income-experiment.html [https://perma.cc/9E72-VLJ5] (discussing Silicon Valley's "love affair" with the idea of basic income); Sara Ashley O'Brien, Why Some Oakland Residents Won't Have To Worry About Rent, CNN MONEY (May 31, 2016), http://money.cnn.com/2016/05/31/ technology/y-combinator-basic-income-oakland-pilot/index.html [https://perma.cc/6M3X-DTZY] (discussing Y Combinator's - a Silicon Valley company that provides seed funding to startups, efforts to establish a basic income pilot in Oakland, California).

197. See generally Robert J. Gordon, The Rise And Fall of American Growth: The U.S. StANDARD of Living Since THE Civil War (2016).

198. Lowrey, supra note 196 ("Silicon Valley is in the midst of a love affair with [basic income], arguing that when robots come to take all of our jobs, we're going to need stronger redistributive policies to help keep families afloat."); see also Manjoo, supra note 10.

199. See Malamud, supra note 71, at 2223.

200. See Kapteyn et al., supra note 191, at 293-94 (explaining that a positive employment effect comes from the "simple notion that in a given period a fixed amount of labour input required to produce a fixed volume of goods and services can be shared between persons who are already employed and those who are unemployed"). 
also provides an answer to technological employment. ${ }^{201}$ In fact, the extent of the effect of technological change can be used to determine how much of an effect regulation should have on the maximum number of hours. If technological change has dramatic effects on unemployment, the maximum number of hours should be made lower. Again, technological unemployment may be a non-problem. If it is not, the egalitarian effects of hours regulation on the mix of jobs (as discussed in the previous section) presents a continuing rationale. ${ }^{202}$ But even if it is, workinghours regulation can also address the unemployment problem to which basic income presents itself as an answer.

\section{Transforming Work}

Transforming the workplace-making it more humane, equitable, and democratic - has long been an egalitarian aspiration of the left. ${ }^{203}$ For a tradition

201. Evidence for the pro-employment effects of working-hours regulation has been mixed. But more recent studies are more sanguine. The reduction in working hours from thirty-nine to thirty-five hours in France in 2000 provides a much-studied test case. Some studies, using matching models or macro data, find large positive effects on employment. See Bruno Crépon et al., RTT, Productivité et Emploi: Nouvelles Estimations sur Données d'Enterprises, 376 ÉCONOMIE ET Statistique 55 (2004); Matthieu Bunel, Aides Incitatives et Déterminants des Embauches des établissements Passés à 35 Heures, 376 Économie et STATISTIQUe 91 (2004); Alain Gubian et al., Les Effets de la RTT sur L'emploi: Des Simulations Ex Ante Aux Évaluations Ex Post, 376 ÉcONOMIE ET StATistiQue 25 (2004). On the other hand, studies using microeconomic data find no effect on employment. See Matthieu Chemin \& Etienne Wasmer, Using Alsace-Moselle Local Laws to Build a Difference-in-Differences Estimation Strategy of the Employment Effects of the 35Hour Workweek Regulation in France, 27 J. LABOR ECON. 487 (2009); Marcello Estevão \& Filipa Sá, The 35-Hour Workweek in France: Straightjacket or Welfare Improvement?, 55 ECON. POL'Y 418 (2008). A recent study, explaining shortcomings of each of these studies and developing a novel identification strategy, finds that France's work-reduction legislation "reduced France's annual unemployment rate by $1.58 \%$ and raised the real GDP by $1.36 \%$ from 2000 to 2007 ." Zaichao Du et al., The Macroeconomic Effects of the 35-h Workweek Regulation in France, 13 B.E. J. OF MACROECONOMics 881, 881 (2012).

202. See supra Part III.B. Note also that other empirical studies find that working-hours regulation has other positive impacts on workers' welfare, such as increases in leisure time and wages, independent of the effect of working-hours regulation on employment. See, e.g., Anders Hayden, France's 35-Hour Week: Attack on Business? Win-Win Reform? Or Betrayal of Disadvantaged Workers?, 34 PoL. \& Soc'y 503, 503 (2006) (finding that “[m]ost . . employees cite quality-of-life improvements"); Hunt, supra note 191, at 117 (finding "the hourly wage rose enough to offset the decline in actual hours worked"); Raposo \& van Ours, supra note 192, at 61 (finding "increased hourly wages"); Oskar Nordström Skans, The Impact of Working-Time Reductions on Actual Hours and Wages: Evidence from Swedish Register-Data, 11 LAB. ECON. 647, 647 (2004) (finding "hourly wages rose sharply").

203. See generally G. A. Cohen, If You'Re an Egalitarian, How Come You’re So Rich? (2000) 
of the Marxist, socialist, or anarchist left, this aspiration is fundamental. ${ }^{204}$ According to these perspectives, not only is it important to reduce economic inequality, but it is also crucial to remove the exploitation and domination that accompanies the exchange of labor in a capitalist market economy. ${ }^{205}$ Exploitation constitutes a kind of unfairness: Some individuals (capitalists) profit from the labor of others (workers). ${ }^{206}$ Likewise, domination is both unequal and illiberal: Individuals do not have full control over how they dispose of their labor or working time.$^{207}$ Accordingly, leftists within this tradition thought mere income redistribution insufficiently inegalitarian. ${ }^{208}$ What was also required was some form of public or democratic ownership of the "principal means of production."209 Only under such conditions would society be able to end exploitation and domination, as well as economic inequality. ${ }^{210}$

Perhaps for this reason, left-leaning scholars were initially skeptical of proposals for basic income. Writing in response to Robert van der Veen and Philippe Van Parijs, ${ }^{211}$ Erik Olin Wright contended that "some form of social ownership of the principal means of production is essential for the development and reproduction" of the kind of society for which they believed basic income would be sufficient. ${ }^{212}$ Basic income would be neither economically nor politically feasible without extensive capital controls and therefore substantial steps toward socialist property institutions. ${ }^{213}$

Nevertheless, and rather avowedly, basic-income proposals make no effort to transform the workplace - at least not directly. In contrast to the socialist left,

204. $I d$.

205. Erik Olin Wright explains the injustice of exploitation and domination (what he terms, alienation) in this way:

In the Marxist tradition, two of the central indictments of capitalism stem from this class relation: first, workers are exploited because they must work harder and longer for capitalists than is needed simply to provide for their own standard of living; and second, they are alienated because they enter into employment relations within which they are deprived of power over both their laboring activities and the fruits of that activity.

Erik Olin Wright, Basic Income, Stakeholder Grants, and Class Analysis, in REDESIGNING REDISTRIBUTION, supra note 29, at 92.

206. Id.

207. Id.

208. Pranab Bardhan \& John E. Roemer, Market Socialism: A Case for Rejuvenation, 6 J. ECON. PERSP. 101, 104-05 (1992) (arguing some form of public ownership is necessary because large-scale income redistribution rests on special and unsustainable conditions).

209. Erik Olin Wright, Why Something like Socialism Is Necessary for the Transition to Something like Communism, 15 THEORY \& SOC. 657, 664 (1986).

210. Id.

211. See generally Robert van der Veen \& Philippe Van Parijs, A Capitalist Road to Communism, 15 THEORY \& Soc. 635 (1986).

212. Wright, supra note 209 , at 658 .

213. Id. at 666. 
basic income could constitute a "capitalist road to communism." 214 By providing nothing more than a cash transfer, basic income at most changes only background conditions of the labor market. Otherwise, labor markets are left untouched and basic income works solely through public institutions.

This feature of basic income is also quite consonant with other features of Rawlsian political philosophy from which luck egalitarianism takes its source. ${ }^{215}$ Several features of Rawlsian philosophy indicate that public policy should be enacted through and apply only to public institutions. ${ }^{216}$ For instance, Rawls wrote,

$[\mathrm{O}]$ nce a suitable minimum is provided by transfers, it may be perfectly fair that the rest of total income be settled by the price system . . . . Moreover, this way of dealing with the claims of need would appear to be more effective than trying to regulate income by minimum wage standards, and the like. It is better to assign to each branch only such tasks as are compatible with one another. Since the market is not suited to answer the claims of need, these should be met by a separate arrangement. ${ }^{217}$

Rawls also says that the Difference Principle applies only to the basic structure of society. ${ }^{218}$ Although Rawls is not always precise about his meaning of the basic structure, one "widespread interpretation" 219 is as follows: The basic structure of a society is defined by "the provisions of its constitution, in such specific legislation as may be required to implement those provisions, and in further legislation and policy which are of central importance but which resist formulation in the constitution itself." ${ }^{220}$ On this view of justice, the scheme just laid out-public policy enacted solely through public institutions, while leaving private economic action unencumbered-therefore becomes quite appropriate. Indeed, restricting the application of the principles of justice to the basic structure yields directly such a "division of labor" in society. In a market society, individuals maximize their self-interest through exchange, while a Rawlsian state selects a maximinning tax function that maximizes the amount of primary goods (or whatever is to be maximinned) going to the least well off. ${ }^{221}$

Moreover, there is a sharper conclusion one can draw from this view of the proper allocation of public policy. In this argument, basic income is superior to

214. See, e.g., van der Veen \& Van Parijs, supra note 211.

215. See, e.g., RAWLS, supra note 25.

216. Id.

217. Id. at 277 .

218. Id. at 263.

219. CoHEN, supra note 203, at 136.

220. Id. at 137.

221. Id. at 127 (writing, "The standard . . Rawlsian application of the difference principle [restricted to the basic structure] can be modeled as follows. There is a market economy in which all agents seek to maximize their own gains, and there is a Rawlsian state that selects a tax function on income that maximizes the income return to the worst off people ...."). 
working-hours regulation precisely because it respects this division between private market exchange and public redistribution. That is, public policy should not invade the market because this site should be left to individuals to bargain and contract on their own. In the case of basic income and working-hours regulation, this view implies the kind of evaluation that we encountered-and rejected-earlier. This evaluation is that basic income is more conducive to individual freedom than working-hours regulation. Basic income respects the right of each individual to decide - to contract - for herself about how much and even whether she should work. Basic income corrects for the inequalities created in the market while also respecting this freedom to contract. Working-hours regulation, on the other hand, seeks to remedy these inequalities directly, but at the cost of individual choice. Other arguments can be made in favor of a relatively strict separation between market freedom and government redistribution, including efficiency arguments. I responded to the basic argument earlier and responses to other arguments can be found elsewhere.

However, the recognition that basic income would have significant, if indirect, impacts on the employment relationship has made friends out of former critics of basic income. Erik Olin Wright, one of these former critics, wrote that "[a] generous, unconditional basic income which would allow employees a meaningful exit option from the employment relation directly transforms the character of power within the class relations of capitalist society."222 For one, basic income would allow people to engage in "non-commodified forms of socially productive activity," such as care-giving labor, art, politics, and community service. ${ }^{223}$ In addition, basic income would give individuals a more "realistic" exit option from the labor market, which would increase their bargaining power with respect to employers. ${ }^{224}$ It is worth emphasizing again that such bargaining power could be used to change any term in the employment contract upon which the employer and employee agree (and that is legally permissible). ${ }^{225}$ And indeed, certainly one term open for negotiation is the number of working hours and the extent of leisure time. Finally, Wright also argues that basic income could have other salient effects on workers' power within the employment relationship, such as the contribution to an increase in union density. ${ }^{226}$ Thus, basic income can substantially alter the balance of class power in a society and therefore indirectly change the terms of the employment relationship.

Yet if it is desirable to transform the employment relationship, why not

222. Wright, supra note 205, at 91-100.

223. Id. at 95 .

224. Id. at 95-96.

225. Recall the discussion in Part III.A.

226. The argument for higher union density is as follows: Employers may prefer to bargain with unions only in tight labor markets. In tight labor markets, there is pressure to increase wages and a labor union - especially a centralized one - can contain this wage pressure within reasonable bounds. By contributing to a tighter labor market, basic income could then encourage employers to be more accepting of labor unions. 
simply do it directly, such as through working-time regulation? Moreover, if this is to be done, can it be normatively justified? Or does Rawls' restriction of the scope of the Difference Principle to society's basic structure disqualify such an attempt? Before directly comparing basic income and working-time regulation, I will first discuss the normative legitimacy of workplace regulation.

Although Rawls says that his principles of justice apply only to the basic structure of society, it is "seriously unclear which institutions are supposed to qualify as part of the basic structure." ${ }^{, 227}$ For example, one can find no argument why the basic structure would not include the public, legally enforceable rules that govern private organizations, such as the family or business firms. In Cohen's interpretation, the basic structure is the "broad coercive outline" of society that would include all legal rules governing such organizations. ${ }^{228}$ If working-hours legislation, by itself or in conjunction with other legal rules, were necessary to maximin the primary goods or real freedom of the least well off, there does not appear to be any Rawlsian principle that would exclude such an option.

Rawls also says that "the market is not suited to answer the claims of need." ${ }^{229}$ One interpretation of the words "not suited" is that it is more efficient to redistribute (or maximin) through government transfers rather than through market institutions. Although without referencing Rawls, such an argument is made by Louis Kaplow and Steven Shavell. ${ }^{230}$ They argue that because redistribution through legal rules is just as distortionary as the tax system, it would be better to choose only efficient legal rules and redistribute only through taxes and transfers. ${ }^{231}$ As I have extensively argued elsewhere, this assumes that redistributive legal rules are always inefficient. ${ }^{232}$ But this is not the case, and it is easy to generate examples where legal rules that reduce income inequality are also more efficient than the status quo rule. ${ }^{233}$ Below, this Article argues that working-hours regulation is an example of such a legal rule-it can both reduce inequality and inefficiency. ${ }^{234}$ Thus, from an efficiency point of view, there is no necessary reason why we shouldn't apply egalitarian principles to the workplace. ${ }^{235}$

If we accept that direct regulation of the workplace is legitimate, we must still

227. COHEN, supra note 203, at 136.

228. Id. at 137 (distinguishing the "noncoercive structure of the family" from the "law of the land" that also governs and structures the family).

229. RAWLS, supra note 25, at 277.

230. Kaplow \& Shavell, supra note 26.

231. Id. at 668 .

232. See Dimick, supra note 24.

233. Id. One example is antitrust legislation. By increasing competition, antitrust law both increases efficiency and lowers prices, which raises the real income of (relatively) poor consumers and lowers the profits of (relatively) rich producers. Thus antitrust law can be both redistributive and efficient.

234. See LEE ET AL., supra note 72.

235. Anderson, supra note 119, at 289. 
ask whether working-time regulation or basic income is more effective at transforming the workplace. If the goal is only to generate more leisure time, then working-time reduction would be superior, simply because of its directness and its applicability to a far larger share of the population. ${ }^{236}$ If the broader goal is to transform the workplace, then basic income could possibly do more than working-hours regulation alone because the greater bargaining power supported by a basic income could be used to enhance any feature of the workplace in favor of the employee. ${ }^{237}$ But if the goal were to transform the workplace, working hours regulation could simply be a part of a larger set of legal rules (or a regime of collective bargaining) that could most certainly transform the workplace more extensively than basic income alone.

\section{E. Universality}

Another feature of basic income that is frequently cited in its favor is its universality. ${ }^{238}$ Under a basic income proposal, every person would receive a transfer, whether rich or poor. ${ }^{239}$ Because it is universal, it has been assumed that basic income would not have the stigma associated with traditional, means-tested welfare programs. ${ }^{240}$ The absence of stigma would have several salient consequences. First, the lack of stigma alone can be thought to benefit the poor insofar as they do not have to bear the social opprobrium associated with poverty programs. ${ }^{241}$ Second, the take-up rate for basic income would be higher than for means-tested programs (and a higher take-up reduces the rate of poverty). ${ }^{242}$ Third, because of its universality, basic income is claimed to be more politically sustainable. For instance, Eduardo Porter writes that basic income "would be politically secure. Programs for the poor are often maligned as poor programs. Indeed, defunding antipoverty programs rarely carries political consequences because the poor rarely vote. It's another story entirely when everyone benefits." 243

There is some limited evidence that universal benefits receive greater public support, ${ }^{244}$ although the case is neither strong nor clear-cut. ${ }^{245}$ However, even

236. LEE ET AL., supra note 72.

237. Van Parijs, supra note 50, at 105.

238. Van Parijs, supra note 29, at 9 (writing "the most striking feature of a basic income is no doubt that it is paid, indeed paid at the same level, to rich and poor alike, irrespective of their income level").

239. $I d$.

240. Id. at 10.

241. Id. at 9-10 (discussing both of these arguments: because "there is nothing humiliating about benefits given to all as a matter of citizenship ... this may count as an advantage in itself. .. [and has a positive] effect ... on the rate of take-up").

242. Id.

243. Porter, supra note 10.

244. Id.

245. There is macro-level evidence that in counties with welfare benefits that are more 
supposing that universal benefits receive more political support than means-tested benefits, can this feature be assumed to hold in the case of basic income? My argument in this section is, "No." There are two reasons for this conclusion. The first reason is that basic income is intrinsically different from other universal benefits. ${ }^{246}$ Other types of benefits are provided as specific kinds of goods-not always but frequently insurance kinds of goods. ${ }^{247}$ In contrast, basic income is simply a cash transfer. ${ }^{248}$ This distinction makes a difference for at least two reasons. In the first instance, such goods are of more value to the rich than is simple cash. Well-funded public schooling-either primary, secondary, or tertiary - may be the best example of a publicly provided, universal good that is supported by rich and poor alike. Education is valued by the rich-if the state provides high-quality schooling then it will find widespread support. The same goes for other universal public goods-pensions, healthcare, and even unemployment insurance. The same cannot be said for a tax-funded basic income. Why do the rich need cash? Why not simply reduce the taxes that the rich pay?

The difference between a public good and a transfer also matters because it is a way of disguising redistribution. When taxes are used to fund public goods available to all, each citizen has access to the good on equal terms. But what appears as access to goods on open and equal terms actually conceals a vast amount of redistribution. ${ }^{249} \mathrm{~W}$ ith a progressive tax system, the rich not only pay for the education of their children, but subsidize the education of the poor as well. Similarly, although benefits such as social security are dependent on one's income and work history, the dispersion in transfers is typically smaller than the inequality in market (that is, pre-tax, pre-transfer) incomes. ${ }^{250}$ In contrast, with

universal, poverty is lower and redistribution is higher. See generally Walter Korpi \& Joakim Palme, The Paradox of Redistribution and Strategies of Equality: Welfare State Institutions, Inequality, and Poverty in the Western Counties, 63 Am. Soc. REV. 661 (1998). However, microlevel studies are much less conclusive. See Mads Meier Jaeger, United But Divided: Welfare Regimes and the Level and Variance in Public Support for Redistribution, 25 EUROPEAN SOC. REV. 723, 723 (2009) (concluding from a review of a large literature that previous research "find[s] little evidence that welfare regimes [defined by features such as universalism] shape public support in any systematic way"); Christian Albrekt Larsen, The Institutional Logic of Welfare Attitudes: How Welfare Regimes Influence Public Support, 41 COMP. POL. STUD. 145, 147 (2008) (labeling as a "dead end" the inconclusive attempts to link institutional features of welfare regimes, such as universalism, with micro-level attitudes about support for the welfare state).

246. See generally Pateman, supra note 46.

247. Korpi \& Palme, supra note 245, at 662 (referring to welfare benefits frequently as "social insurance").

248. Van Parijs, supra note 29, at 3.

249. Korpi \& Palme, supra note 245, at 661 (observing the "[o]utcomes of market-based distribution are often more unequal than those of earnings-related social insurance programs," that is, even when benefit levels depend on market income, benefits are distributed more equally than are market incomes).

250. Whether disguising the extent of redistribution is a normatively acceptable thing to do is an interesting question, but not one addressed in this Article. 
cash transfers (as in basic income), the redistributive effects are obvious. With only knowledge of the tax schedule and the amount of the grant, one can easily determine who gains and who losses under basic income. Because it is simply a cash transfer, basic income quite transparently separates recipients into net beneficiaries and net payers ${ }^{251}$-a feature that is not so obvious when considering public goods.

The second reason that broad public support will not transfer to universal basic income is that most other universal schemes have a close association with individuals' work contributions. ${ }^{252} \mathrm{~A}$ strong social norm exists-legitimate or not-that individuals' contribute toward their own income. ${ }^{253}$ Social security benefits, as just mentioned, depend on work history and prior income-as do unemployment benefits. ${ }^{254}$ The provision of education recognizes that individuals cannot contribute unless they have the basic skills and knowledge to do so. Even health care can be viewed as a precondition of work-individuals cannot contribute unless they are healthy. ${ }^{255}$ Even the exception proves the rule. Disability benefits are distributed only on the condition that individuals cannot work.

Thus, we should expect an income transfer that emphatically disregards an obligation to work to be met with heavy skepticism. Indeed, despite the frequent recognition that basic income's universalism should lead to broad public support, ${ }^{256}$ other journalistic commentators intuitively recognize the problem of this assumption. For instance, Ezra Klein writes:

251. Van Parijs, supra note 29, at 11.

252. Feminist scholars have frequently observed the close association with paid labor and state provision of welfare benefits. See generally Ann Shola Orloff, Gender and the Social Rights of Citizenship: The Comparative Analysis of Gender Relations and Welfare States, 58 AM. Soc. REv. 303 (1993). A critique of the welfare state follows from this observation, but responding to it is beyond the scope of this Article.

253. Samuel Bowles \& Herbert Gintis, Reciprocity, Self-Interest, and the Welfare State, 26 NORDIC J. POL. ECON. 33, 33 (2000) (arguing "voters support the welfare state because it conforms to deeply held norms of reciprocity and conditional obligations to others").

254. Ezra Klein, A Universal Basic Income Only Makes Sense If Americans Change How They Think About Work, Vox (June 1, 2016), http://www.vox.com/2016/6/1/11827024/universal-basicincome [ https://perma.cc/4CWH-Y2CP].

255. The connection between work and health insurance can certainly be questioned. Perhaps this is why universal health insurance has been so difficult to achieve in the United States where the norm of deservingness is perhaps strongest.

256. Porter, supra note 10 ("Being universal - that is, for the homeless and the masters of the universe alike - the program would be free of the cumbersome assessments required to determine eligibility. It would also escape the stigma typically attached to programs for the poor."); James Surowiecki, The Case for Free Money, New YORKER (June 20, 2016), http://www.newyorker.com/ magazine/2016/06/20/why-don't-we-have-universal-basic-income [ttps://perma.cc/XE7M-FZ8W] ("But the appeal of a basic income — a kind of Social Security for everyone — is easy to understand ... . [I]f it's truly universal, it could help destigmatize government assistance.”). 
But the case against a UBI [universal basic income] flows from the premise that this much cultural change around work is effectively impossible. In that world, a UBI would become a form of welfare, and its recipients would be pitied and derided. An angry public would resent handing over cash to the undeserving poor and would forever be agitating to cut or eliminate the checks. ${ }^{257}$

Thus, basic income is unlikely to evade that stigma that is avoided with other types of universal transfers. Indeed, one can see this problem as simply an application of Anderson's critique of luck egalitarianism. ${ }^{258}$ By separating people into income beneficiaries and payers, basic income essentially communicates the message that certain individuals are deemed inadequate and unable to contribute to society or provide for themselves. ${ }^{259}$ As discussed above, although some individuals may have no qualm accepting such a judgment, others-those who do desire to contribute-will feel quite different. ${ }^{260}$ Thus, basic income's universalism does not save it from making demeaning judgments about individuals' abilities. And not only are these judgments harmful to the poor recipients of basic income. Because of what it communicates, this judgment will also reduce public support for the policy. ${ }^{261}$

In the aspects discussed here, working-time regulation would much more easily fulfill the requirements of a universal benefit. First, as already discussed, the consequences of working-time regulation-more leisure-would be available to a much broader portion of the population. This feature will engender broader support among the population - to the extent this effect exists. Second, the benefit is quite explicitly tied to work. Indeed, the reduction of hours of working time is only available to those who work. Working-time regulation is thus an earned benefit, available to those who contribute.

\section{F. Efficiency}

Another attribute often cited in favor of basic income is its efficiency. ${ }^{262}$ Basic income would generate at least two kinds of economic efficiency relative to other or existing policies. The first efficiency is the savings created by simpler administration. ${ }^{263}$ The second derives from improved incentives in individuals'

257. Klein, supra note 254.

258. See generally Anderson, supra note 119.

259. $I d$.

260. Id.

261. Matthews, supra note 2. Skepticism of the universalism of basic income is also confirmed when comparing it to an alternative proposal, the negative income tax. One could then propose that instead of basic income, we adopt instead a negative income tax.

262. See Liscow, supra note 24.

263. Guy Standing, Global Labour Flexibility: Seeking Distributive Justice 362-63 (1999) (writing that an unconditional basic income "would save on administration costs because it would simplify the complex schemes, make them more transparent and reduce the amount of 
work-leisure choices. ${ }^{264}$

Let us start with administrative efficiency. ${ }^{265}$ Under current welfare policies, current and potential recipients face a range of specific, sometimes in-kind benefits-housing, food stamps, etc.- - each with its own means test. Not only is this time consuming and confusing for recipients, but staffing and processing each of these programs also requires significant resources. Replacing these welfare policies with basic income would eliminate nearly all of these administrative costs. With a basic income, the only significant cost would be the administration of the tax-revenue system (if basic income is financed in this way) - a cost anyway under the current welfare regime.

A possibly more significant efficiency gain under basic income is its effect on individuals' work-leisure choices. Economists generally agree that tax and welfare policies have some "distortionary" effects on individuals' decision about how much time to allocate between work and leisure. ${ }^{266}$ To the extent that tax and welfare policies reduce the reward to work, we should expect people to correspondingly choose more leisure over paid employment. ${ }^{267}$ This effect of taxation is dubbed the "substitution" effect. ${ }^{268}$ To the extent that this work-leisure trade-off differs from a hypothetical, perfectly competitive labor market, taxation distorts an individual's economic choices. ${ }^{269}$

Proponents of basic income argue that it would significantly, if not vastly, reduce the distortionary effects of current welfare policies. ${ }^{270}$ As critics of welfare programs have long argued, means testing creates substantial disincentives to work because earning more income can cause recipients to lose their welfare

intrusive enquiry").

264. Van Parijs, supra note 29, at 10-11, 12, 13, 14 (explaining how basic income removes "unemployment trap" associated with traditional, means-tested welfare benefits).

265. For a critique of the claim of basic income's administrative efficiency, see generally Jurgen De Wispelaere \& Lindsay Stirton, The Administrative Efficiency of Basic Income, 39 PoL'Y \& POL. 115 (2011).

266. Joel Slemrod \& Jon Bakija, Taxing Ourselves: A Citizen's Guide to the Debate OVER TAXES 121-22 (4th ed. 2008) (“[M] ost taxes, including income and consumption taxes, reduce the marginal reward for working. Work [in contrast to leisure] becomes less attractive because working that extra hour or taking on a second job buys fewer consumption goods and services. Put differently, leisure and other nonmarket activities become more attractive ....").

267. Id.

268. Id. at 122 ("The reduced after-tax return to working provides an incentive to substitute more leisure and nonmarket endeavors for less work and less consumption of goods and services. Economists call this impact of taxes the substitution effect ....").

269. Id. at 120-21 (explaining "the baseline for measuring the economic cost of taxation is how the economy would operate in the absence of any taxes . ..." This hypothetical, perfectly competitive market environment is defined as efficient and departures from it - for example, those created by taxes - are distortionary, or inefficient.).

270. Van Parijs, supra note 29, at 10-14 (again, explaining how basic income removes the "unemployment trap"). 
income. ${ }^{271}$ The effect is no different than a sharp increase in the marginal tax rate as income rises. ${ }^{272}$ In fact, economists analyze these means-testing discontinuities in precisely such language. ${ }^{273}$ Therefore, current welfare policies discourage work and thereby generate significant economic loss. ${ }^{274}$

A basic income would entirely eliminate the distortionary substitution effects of existing welfare policies. Because basic income is universal and unconditional, its receipt does not depend on work choices or income. ${ }^{275}$ It is even viewed as work-promoting by its advocates. According to Van Parijs, "Since you can keep the full amount of your basic income, whether working or not, whether rich or poor, you are bound to be better off when working than out of work." 276 Advocates of basic income thus view this feature as a major benefit. Van Parijs in particular refers to the distortionary problem of welfare policy as the "unemployment trap," and writes that "[t] he abolition of the means test, as we have seen, is intimately linked to the removal of the unemployment trap.",277 To be sure, as all would acknowledge, distortions on the tax side would continue to exist, but these prevail under existing policy in any case.

Despite these efficiency advantages, basic income also has the potential to generate quite significant inefficiencies, as well. While, in the substitution effect, basic income makes work relatively more valuable than leisure, basic income has an additional effect, called the income effect. ${ }^{278}$ The income effect is the effect that changes in income have, in this case, on consumption, including work and leisure. ${ }^{279}$ Everything equal, economists predict that an increase in income will lead individuals to increase their leisure to some extent. ${ }^{280}$ In other words, with

271. See, e.g., Daniel Shaviro, The Minimum Wage, the Earned Income Tax Credit, and Optimal Subsidy Policy, 64 U. CHI. L. REV. 405, 423-27 (1997) (explaining how the loss of welfare benefits, as one moves up the income scale from longer work or a new job, effectively creates high marginal tax increases and discourages work).

272. Id.

273. Id.

274. See, e.g., Nicole Maestas et al., Does Disability Insurance Receipt Discourage Work? Using Examiner Assignment to Estimate Causal Effects of SSDI Receipt, 103 AM. ECON. REV. 1797 (2013); Susan Chen \& Wilbert van der Klaauw, The Work Disincentive Effects of the Disability Insurance Program in the 1990s, 142 J. ECONOMETRICS 757 (2008); Janet E. Kodras, Labor-Market and Policy Constraints on the Work Disincentive Effect of Welfare, 76 ANNALS Ass'N AM. GEOGRAPHERS 228 (1986).

275. Van Parijs, supra note 29.

276. Id. at 11 .

277. Id. at 14 .

278. SLEMROD \& BAKIJA, supra note 266, at 122.

279. Id. ("Besides changing the marginal reward to working, most taxes make you poorer, and when people are poorer, they tend to cut back at least a bit on all the things they value, including leisure.").

280. This is on the assumption that leisure is a normal good, defined as one that increases with income (or wealth). If leisure were an inferior good, the amount of leisure would decrease as income increases. 
an increase in income, people will need to work less to satisfy their consumption preferences. ${ }^{281}$ Even more intuitively, why would anyone work if the government provides her with a no-strings-attached income? Thus, by reducing the incentive to work, basic income may also worsen economic efficiency, causing output to drop beneath its optimal level. ${ }^{282}$

Whether basic income improves efficiency (via the substitution effect) or worsens efficiency (via the income effect) is an empirical question. And, with only limited research to bring to bear on this issue, it is difficult to definitively answer. Nevertheless, two points are worth observing. First, advocates face a dilemma when arguing on efficiency grounds. On the one hand, advocates tend to minimize the concern raised by the income effect. They will point to studies that support their view that basic income does not discourage people from working. ${ }^{283}$ On the other hand, advocates are much more enthusiastic about abolishing means testing and encouraging work along the lines of the substitution effect. ${ }^{284}$ But because both substitution and income effects are economic decisions made by the same individuals, it seems unlikely that advocates can have it both ways. Either substitution and income effects will both be salient or they will both not be.

The second point relates to the level of basic income. And in this case again, advocates are caught in a thorny dilemma. Clearly, the level of the basic income will have some effect on work incentives. At a high enough level, most people will continue to work in only the most intrinsically rewarding jobs. Conversely, at a sufficiently low level, we would expect work incentives to be only marginally affected. At the same time, the benefits of basic income are precisely the opposite. Basic income is most liberating at its most generous level, while least at its lowest level. Basic income, therefore, faces some difficult trade-offs. ${ }^{285}$

We can now address the efficiency issues of working-time regulation. The first thing to note is that administrating working-time regulation also entails costs. The primary costs will be those of inspection and enforcement- the same types of costs as currently exist under the FLSA. ${ }^{286}$ How large these costs are depends partly on how effective the government and the public want the policy to be-a

281. SLEMROD \& BAKIJA, supra note 266, at 122 ("Because the belt tightening of taxes causes people to cut back on leisure, it causes people to work more than otherwise.") (emphasis in original). Conversely, an increase in income will cause individuals to increase leisure and reduce work.

282. Most studies will show a minor decline in work effort. For a review, see Karl Widerquist \& Allan Sheahen, The United States: The Basic Income Guarantee-Past Experience, Current Proposals, in BASIC InCOME WORLDWIDE: Horizons OF REFORM 11 (2012).

283. Porter, supra note 10.

284. Avraham et al., supra note 24, at 1145.

285. Van Parijs does squarely recognize this trade-off, writing, "The basic fact is that the more material incentives one wishes to provide (for a given minimum income) to people earning at the bottom of the earnings scale, the more one needs to decrease the material incentives higher up." Van Parijs, supra note 29, at 19.

286. On the enforcement of the FLSA, see CRAIN ET AL., supra note 53, at 782-84. 
consideration no different than with basic income. One countervailing feature with working-time regulation is the possibility of co-enforcement by secondary associations. ${ }^{287}$ Labor unions, worker centers, or works councils are the most relevant examples. ${ }^{288}$ Although these methods are not themselves costless (for example, union activities are funded by member-paid union dues), their proximity to workers and the workplace gives them better access to information, which significantly lowers the cost of enforcement. ${ }^{289}$ These features may make the enforcement of working-hours regulation cheaper than the administration of basic income.

Both basic income and working-time regulation, therefore, entail administrative costs, and it is not entirely clear nor obvious which is cheaper in these terms. As such, neither constitutes a clearly superior policy choice.

However, the comparison is clearer when we consider other kinds of economic efficiency. First, note that if labor markets are perfectly competitive, any attempt to regulate working hours will be inefficient. ${ }^{290}$ But with any departure from such a scenario, and in particular any imperfections in the way working time is set, then there is scope for policy to increase efficiency. ${ }^{291}$ The question, then, is just how competitive labor markets are. At first glance, they would seem to be very competitive. Labor is relatively mobile, and therefore few employers can exercise monopsony power. ${ }^{292}$ Workers are typically free to sell their labor to several different employers.

But even with many potential buyers, there can exist substantial market imperfections - which can give employers a kind of de facto monopsony power. ${ }^{293}$ When this is the case, employers will have an incentive to set the length

287. See Paul Weiler, Governing the WorkPlace 152-61 (1990) (discussing the roles of the government and labor unions in enforcing labor and employment laws and the drawbacks of exclusively relying on the former).

288. See generally Janice Fine \& Jennifer Gordon, Strengthening Labor Standards Enforcement Through Partnerships with Workers' Organizations, 38 POL. \& SoC'Y 552 (2010).

289. Enforcement of various kinds of labor laws depend on the presence of a union at the workplace. See, e.g., David Weil, Enforcing OSHA: The Role of Labor Unions, 30 INDUS. REL. 20, 20 (1991) (finding unionized firms were "more likely to receive safety and health inspections, face greater scrutiny in the course of those inspections, and pay higher penalties for violating health and safety standards than comparable nonunion establishments").

290. This follows from the so-called first fundamental theorem of welfare economics, which says that when markets are complete, any competitive equilibrium is necessarily Pareto optimal. Andreu MAS-COlellet AL., Microeconomic TheORY 308 (1995). In this scenario, no regulation can make any Pareto superior change.

291. See id. at 308-09 (listing the departures from perfect competition - market failures - that justify Pareto-improving market interventions).

292. Whereas "monopoly" means "one seller," "monopsony" means "one buyer."

293. The White House's Council of Economic Advisers recently issued a policy brief discussing the sources of labor market monopsony to explain rising income inequality-both between workers and between firms and workers. Sources of monopsony power in the labor market include: (1) market concentration among firms, (2) employer collusion, (3) employer use of non- 
of the working day longer than employees prefer. At the same time, given the imperfections in the market, employees will accept these less-than-preferred terms because this is the best they can do. Economists would certainly debate the existence and extent of labor market imperfections - just as they do in discussions of the impact and efficiency of the minimum wage. ${ }^{294}$ I cannot hope to resolve the debate in this Article; but one might point to the trend in working hours over the last few decades as prima facie evidence of the inefficiency of setting working hours in the labor market. ${ }^{295}$ As the fall in working time has stalled or even reversed, even in the face of growing labor productivity, a simple interpretation is that capital has gained the upper hand over labor in determining hours at work. $^{296}$

If labor market imperfections exist, and employers set hours longer than employees prefer, then legislation that reduces working time will unambiguously increase efficiency. Unlike basic income, there is no trade-off in terms of the efficiency effects. This will be even more likely the case when labor-market policy gives workers sufficient discretion over how much and when they choose more leisure. When evaluating policies in terms of efficiency then, working-time regulation stands as a clear winner.

\section{G. The Environment}

A final criterion by which we can evaluate basic income and working-time regulation is their effects on the environment. There can be little doubt that concerns about climate change and ecological sustainability are now foremost in many peoples' minds. ${ }^{297}$ How social policy impacts the environment is thus an extremely crucial question.

It should first be noted that arguments for basic income are rarely, if ever, linked to environmental concerns in any fundamental way. ${ }^{298}$ Indeed, if anything, the prima facie case for basic income is anti-environment. ${ }^{299}$ By increasing the

compete agreements, (4) search costs and labor market frictions, (5) "job lock" and employersponsored health insurance, and (6) regulatory barriers to worker mobility. See generally Council of Economic Advisers Issue Brief, Labor Market Monopsony: Trends, Consequences, and Policy Responses (Oct. 2016), https://obamawhitehouse.archives.gov/sites/default/files/page/files/ 20161025_monopsony_labor_mrkt_cea.pdf [https://perma.cc/AX9Z-3FNL].

294. For sources and research on labor market monopsony, see $i d$.

295. SCHOR, supra note 89 , at 28-34 (analyzing the rise in working hours).

296. Id. at 79-82.

297. To take simply a recent headline as evidence of this, see Lizette Alvarez \& Frances Robles, Intensified by Climate Change, 'King Tides' Change Ways of Life in Florida, N.Y. TimES (Nov. 17, 2016), https://www.nytimes.com/2016/11/18/us/intensified-by-climate-change-kingtides-change-ways-of-life-in-florida.html?_r=0 [https://perma.cc/Y64Y-6YSP].

298. Jan Otto Andersson, Basic Income from an Ecological Perspective, 4 BASIC INCOME STUD. 1, 2 (2009) ("In his treatise Real Freedom for All, Van Parijs . . does not use ecologically related arguments in favor of a [basic income].”).

299. Id. at 3. Andersson also notes that Van Parijs' argument in Real Freedom for All "implies 
amount of income going to the poor-who are likely to spend, rather than save, the entire amount-basic income is pro-consumption. To that extent, basic income increases the resource burden on the environment. Thus, "One sees, intuitively, a contradiction between soliciting an adequate unconditional [basic income] and asking for an ecologically acceptable use of our environmental resources. ${ }^{300}$ Indeed, many have frequently noted the puzzle of support for basic income by the Green movement. Van Parijs suggests that such support can be explained by Green-movement members' embrace of a "postmaterialist" values orientation. ${ }^{301}$ Yet he also observes that "a crucial - if not the crucial-argument for basic income must be that . . basic income is growth-friendly."302

That said, proponents of basic income with an ecological bent have suggested ways of making basic income and concern for the environment more compatible. Perhaps the most straightforward way of accomplishing this task is to finance basic income out of "green taxes," such as taxes on pollution or other environmental public harms. ${ }^{303}$ As Andersson observes, "A solution that curbs excessive consumption patterns and enhances the life chances of the poor at the same time is superior to a scheme that is either purely redistributive or purely eco-efficient without regard to distributive justice." 304

In contrast to basic income, the compatibility of working-time regulation and environmental sustainability is much more straightforward. ${ }^{305}$ By reducing working hours, working-time regulation can be a way of using increased productivity to substitute leisure for consumption-or of outright reducing production and consumption. ${ }^{306}$ Indeed, several researchers have written about working-time regulation precisely as a means to reduce the resource burden on the environment.

In a recent paper, Kyle W. Knight, Eugene A. Rosa, and Juliet B. Schor empirically examine "the hypothesis that shorter working hours are significantly associated with lower environmental pressures." ${ }^{307}$ They investigate two different pathways through which reduced working hours could lower pressure on the

that a [basic income] is likely to impose a burden on both the economy and the ecology." Id.

300. Andersson, supra note 298, at 1.

301. Philippe Van Parijs, Competing Justifications for Basic Income, in PhILIPPE VAN PARIJS, ARguing For BASIC InCOME 3, 28 (Philippe Van Parijs ed., 1992).

302. Id.

303. Andersson, supra note 298 , at 5

304. Id.

305. See generally Juliet B. Schor, Sustainable Consumption and Worktime Reduction, 9 J. INDUS. ECOLOGY 37 (2005) (arguing "it is difficult to imagine a globally ethical, timely, and politically feasible resolution to the global ecological crisis in which populations in the North do not reduce the number of hours worked per capita").

306. Id.

307. Kyle W. Knight et al., Could Working Less Reduce Pressures on the Environment? A Cross-National Panel Analysis of OECD Countries, 1970-2007, 23 Global EnvTl. Change 691, 691-92 (2013). 
environment. ${ }^{308}$ They call the first pathway the "scale effect": All else equal, shorter hours of work should reduce the scale of the economy. ${ }^{309}$ The second pathway is called the "compositional effect." 310 Working longer affects consumption patterns and leads to the consumption of goods and services that put more pressure on the environment. ${ }^{311}$ For instance, "Households with less time and more money will choose timesaving activities and products, such as faster transportation, which are often more environmentally intensive." ${ }^{312}$ Using data for twenty-seven high-income OECD countries from 1970 through 2007, the authors find strong empirical support for the first mechanism and moderate support for the second. ${ }^{313}$ Thus, there is evidence that shorter working hours can reduce pressure on the environment.

The conclusion is that if one wants to promote greater free time for workers and reduce pressure on the environment, working-time regulation offers a far more preferable choice than basic income in achieving these objectives.

\section{CONCLUSION}

As explored in this Article, basic income has many desirable attributes. As this Article has also demonstrated, working-hours regulation surpasses, or at least achieves, what basic income does, evaluated on these same attributes. Given the choice, this Article recommends that further attention, research, and promotion be given to working-time regulation than to basic income. But is such a choice necessary? Why not adopt both basic income and working-time regulation? As alluded to in the introduction, there are many reasons for why adopting both may not be feasible. First, the accomplishment of either would be a substantial political achievement. Legislating either would require considerable political resources, mobilization, and capital. Asking for both would in many countries place unreasonable demands on those resources. There is also the problem of "institutional complementarities" mentioned in the introduction. The expectation of employment is built into most existing welfare-state policies. A reform of working-time regulation-premised on work-would complement those existing policies. In contrast, basic income would mark a substantial change in welfarestate policy. Not only does this make basic income more difficult to achieve, but it also makes it more uncertain in its consequences. Finally, there is also the argument of political feasibility. Working-time regulation merely involves a modification-more or less substantial depending on the actual version adopted - to an already existing set of policies. ${ }^{314}$ Again, depending on the version adopted, the tax revenues required for such a change could be quite

308. $I d$.

309. Id.

310. Id.

311. Id. at 694 .

312. Id.

313. Id.

314. Matthews, supra note 2. 
modest. In contrast, the adoption of basic income would involve enormous revenue costs. Even granting each citizen in the United States a modest basic income of $\$ 10,000$ per year would amount to $\$ 3$ trillion annually. ${ }^{315}$ Federal spending on current welfare programs amounts in comparison to around $\$ 600$ billion. ${ }^{316}$ Put another way, a basic income would cost five times as much as current welfare spending. For many commentators, this fact alone is sufficient to end any serious discussion about the political possibilities of a basic income in the United States.

In short, the normative desirability of a policy is not always sufficient to ensure its success. Basic income may well be viable-even feasible. But workingtime regulation can achieve nearly all that we would want from basic income-and do so on a broader, more egalitarian basis. Given that, and the modest political constraints on policy, the choice between basic income and working-time regulation is real, relevant, and augurs in favor of the latter.

315. Porter, supra note 10.

316. Mike Konczal, No, We Don't Spend \$1 Trillion on Welfare Each Year, WASH. Post (Jan. 12, 2014), https://www.washingtonpost.com/news/wonk/wp/2014/01/12/no-we-don't-spend-1trillion-on-welfare-each-year/?utm_term=.0a271cdff17b [https://perma.cc/H6KN-ZTQH]. 